\title{
Acetone-butanol-ethanol Fermentation from Different Pulp and Paper Manufacturing Process Side-streams
}

\author{
Sandra Sandar, ${ }^{\mathrm{a}, *}$ Ming Yang, ${ }^{\mathrm{b}}$ Ossi Turunen, ${ }^{\mathrm{a}}$ Jouko Vepsäläinen, ${ }^{\mathrm{c}}$ Ari Pappinen, ${ }^{\mathrm{a}, *}$ and \\ Suvi Kuittinen ${ }^{\text {a,* }}$
}

\begin{abstract}
The pulp and paper industry produces a diverse range of side-streams from multi-stage processes, but these remain underutilized despite their high potential for use as biofuels. This study investigated acetone-butanolethanol (ABE) fermentation by Clostridium acetobutylicum DSM 1731 from the side-streams of three different stages of the pulp and paper manufacturing process (PI, PII, and PIII). Biomass specimens with and without water washing were pretreated with $0.2 \% \mathrm{H}_{2} \mathrm{SO}_{4}$ at $180{ }^{\circ} \mathrm{C}$ for 10 min, followed by enzymatic hydrolysis, to obtain fermentable sugars. The results showed that the produced $\mathrm{ABE}$ solvent concentrations were 12.8 $\mathrm{g} / \mathrm{L}, 5.2 \mathrm{~g} / \mathrm{L}$, and $6.3 \mathrm{~g} / \mathrm{L}$ from PI, PII, and PIII, respectively. The butanol yields of PI, PII, and PIII were $0.25,0.18$, and $0.19 \mathrm{~g} / \mathrm{g}$ sugars, respectively. Among the tested side-streams, PI was shown to have potential as a feedstock for butanol production without prewashing prior to dilute acid pretreatment, enzymatic hydrolysis, and microbial fermentation.
\end{abstract}

Keywords: Acetone-butanol-ethanol (ABE) fermentation; Butanol; Clostridium acetobutylicum, Hydrolysis; Pretreatment; Pulp and paper manufacturing process side-streams

Contact information: a: School of Forest Sciences, University of Eastern Finland, P.O. Box 111, 80101 Joensuu, Finland; b: College of Life Sciences, Hebei Agricultural University, Baoding 071001, Hebei, China; c: School of Pharmacy, University of Eastern Finland, P.O. Box 1627, FI70211 Kuopio, Finland; *Corresponding authors: sandra.sandar@uef.fi, ari.pappinen@uef.fi, suvi.kuittinen@uef.fi

\section{INTRODUCTION}

Global environmental concerns, rising energy demand, and the need to reduce greenhouse gas emissions are driving the search for new opportunities in the energy sector. In particular, biofuel production derived from the microbial fermentation of low-cost feedstocks, such as agricultural residues and industrial wastes has been shown to be a promising alternative to petroleum-based fossil fuels. Biofuel production from pulp and paper manufacturing process side-streams has been considered as one possible solution to these challenges. Paper mill sludge contains a high content of lignocellulose and has a welldispersed structure, which catalyzes butanol and ethanol production (Kang et al. 2010; Gogoi et al. 2018).

Pulp and paper manufacturing involves five major processes: mechanical, chemical, chemo-mechanical, thermo-mechanical pulping, and papermaking (Ashrafi et al. 2015). Side-streams and waste from pulp and paper mills can be divided into four main categories, namely, (i) rejects, (ii) de-inked sludge, (iii) primary sludge, and (iv) secondary sludge (Gottumukkala et al. 2016). In this study, PII and PIII are primary and secondary sludges, whereas PI is the rejects from pre-hydrolysis stage before kraft pulping (Fig.1). In 2007, global production of paper and board was estimated at approximately 384 million tons (Pätäri et al. 2011), and USA and Japan generated nearly 5 million tons of paper mill sludge annually (Boshoff et al. 2016). In 2018, the Finnish pulp and paper industry 
produced about 19 million tons of pulp, paper and board, whereas fiber sludge, biosludge and primary sludge generated about 3.9 million tons, and approximately 68,000 tons of pulp and paper mill waste as landfill (FFI 2018; Hassan et al. 2019). Moreover, the Waste Act in Finland allows for the valorization of the side-streams from pulp and paper industry as by-products (FFI 2018).

The prospective of the pulp and paper manufacturing process side-streams for biogas (Gottumukkala et al. 2016), butanol (Guan et al. 2016), ethanol (Boshoff et al. 2016), and lactic acid (Marques et al. 2008) production has received some attention. Biobased butanol $\left(\mathrm{C}_{4} \mathrm{H}_{9} \mathrm{OH}\right)$ is an advanced biofuel and is a potential feedstock for various chemicals, as well as an important intermediate in chemical synthesis with a wide range of industrial uses (Dürre 2008; Tashiro et al. 2013; Yang et al. 2013). It has been proposed, therefore, as the next generation of alternative biofuels, due to its unique properties that are superior to ethanol (i.e., blending efficiency with gasoline at any percentage, high energy content, high hydrophobicity, less corrosiveness, and low vapor pressure) (Dürre 2008; Tashiro et al. 2013; Karimi et al. 2015). Biochemically, butanol is produced from sugars by acetone-butanol-ethanol (ABE) fermentation with Clostridium acetobutylicum, with a typical product ratio of ABE 3:6:1 (Yang et al. 2013). However, the production of biobutanol from pulp and paper manufacturing process side-streams may require the ABE process integration to the processes in the existing pulp and paper mill. Potential sugarcontaining side-streams originate from different stages of the process. The present research focused on side-streams that are currently unutilized (Fig.1).

The kraft pulping process involves an alkaline pretreatment as a carbohydrate reaction (Saville 2011). The benefits of alkali pretreatment include the removal of lignin and the improvement of cellulose digestibility. However, drawbacks include the high cost of the alkali and the large amount of wastewater produced, which limit its application (Rydholm 1965; Talebnia et al. 2010). On the other hand, dilute sulfuric acid pretreatment has been applied to a wide range of lignocellulosic biomass, resulting in high solubility of hemicellulose, altering lignin, and enhancing the availability of cellulose for subsequent enzymatic hydrolysis (Kumar et al. 2009). It has been shown that a pre-handling step to the pretreatment processes, such as prewashing and de-ashing, would enhance the efficiency of pretreatment and increase the hydrolysis yield for bioethanol and biobutanol production (He et al. 2014; Guan et al. 2016; Huang et al. 2016). In many pretreatment studies, the prewashing step seems to be an optional operation, since the ash content in lignocellulose biomass can absorb more solvent than lignocellulose fibers (He et al. 2014; Tang et al. 2019). Therefore, water washing is usually applied to remove the soil or air dust portions of the ash (extractable ash) in order to increase the pretreatment efficiency (He et al. 2014).

Phillips et al. (2013) earlier proposed that much of the equipment used in the pulp and paper mill manufacturing process, e.g., wood chipping, digesting, mechanical refining, and evaporation, can be used for pretreatment operations, since they may already be present in the prospective pulp mills. Paper sludge with a high ash content has been reported to have an additional advantage for butanol fermentation, while other studies have found that kraft paper mill sludge requires a partial removal of ash to enhance its enzymatic digestibility in $\mathrm{ABE}$ fermentation using $C$. acetobutylicum (Yang et al. 2013; Gottumukkala et al. 2016; Guan et al. 2016). There is a considerable debate between the benefit of water washing to remove ash, and the advantage of a high ash content in pulp and paper manufacturing process side-streams as a feedstock in butanol production. Moreover, evaluation of prewashing effects on pretreatment or on the enzymatic hydrolysis 
of pulp and paper manufacturing process side-streams from different pulping processes has been rarely reported (Guan et al. 2016).

Therefore, the aim of this study was to characterize different pulp and paper manufacturing process side-streams and their chemical composition, and to test them with and without prewashing before pretreatment, enzymatic hydrolysis, and ABE fermentation.

\section{EXPERIMENTAL}

\section{Pulp and Paper Manufacturing Process Side-streams Materials}

Three pulp and paper manufacturing process side-streams (PI, PII, and PIII) were investigated for butanol production by $\mathrm{ABE}$ fermentation using $C$. acetobutylicum. The three side-streams used in this study were acquired from two Finnish pulp, paper, and board mills, one using the mechanical pulping process and the other using the chemical pulping process, as shown in Fig. 1. The side-streams originated from different stages of kraft pulping and the mechanical pulping process of mixed species softwood biomass, such as rejects from pre-hydrolysis of the pulping process, and wastewater treatment sludge (Table 1). They also contained residues of cooking and clarifying chemicals, bark residues, and wood knots, for example.

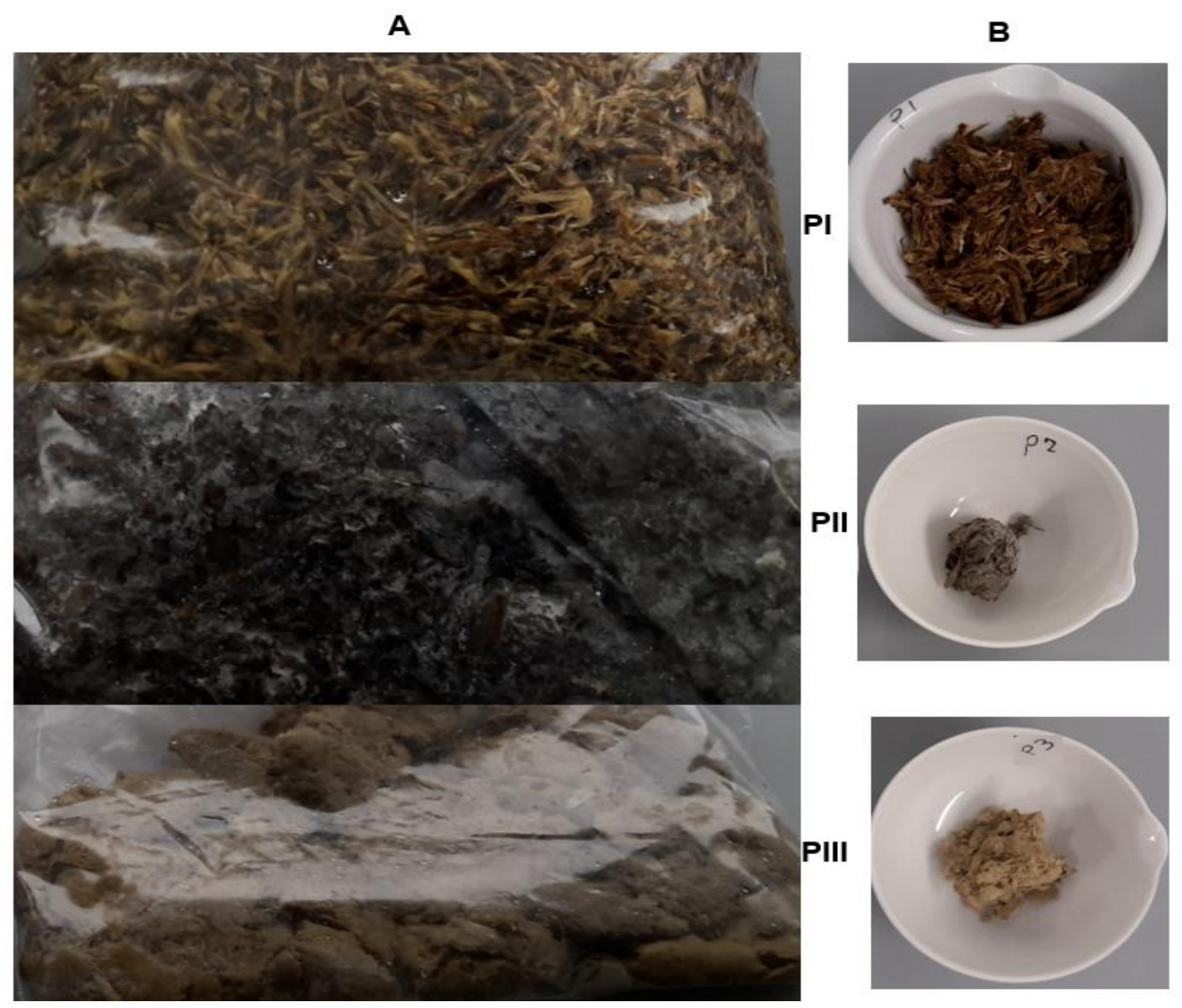

Fig. 1. The samples used in this study: PI and PII from kraft pulping and PIII from mechanical pulping processes (A) Original samples (B) Dried samples 
Table 1. Origin of the Studied Pulp and Paper Manufacturing Process Sidestreams

\begin{tabular}{|c|c|c|}
\hline $\begin{array}{l}\text { Name of Pulp and } \\
\text { Paper Process Side- } \\
\text { streams }\end{array}$ & Origin: Pulp Process Stage & Sample Type \\
\hline PI & $\begin{array}{l}\text { Kraft pulping, pre-hydrolysis } \\
\text { (Rejects) }\end{array}$ & $\begin{array}{l}\text { Softwood, contains fiber materials, } \\
\text { bark residues, wood knots, } \\
\text { residues from wood handling }\end{array}$ \\
\hline PII & $\begin{array}{l}\text { Kraft pulping, final process } \\
\text { sludge (Primary sludge) }\end{array}$ & $\begin{array}{l}\text { Pressed sludge, contains fiber } \\
\text { residues, cooking chemicals, } \\
\text { traces etc. }\end{array}$ \\
\hline PIII & $\begin{array}{l}\text { Mechanical pulping, sludge } \\
\text { from wastewater treatment } \\
\text { (Secondary sludge) }\end{array}$ & $\begin{array}{c}\text { Softwood, contains fiber residues } \\
\text { etc. }\end{array}$ \\
\hline
\end{tabular}

\section{Methods}

\section{Pretreatment procedure}

Before selecting suitable pretreatment conditions for the tested samples, the PI samples were pretreated with water and two concentration gradients of sulphuric acid $\left(\mathrm{H}_{2} \mathrm{SO}_{4}\right) 0.1$ and $0.2 \%(\mathrm{w} / \mathrm{v})$ at $180{ }^{\circ} \mathrm{C}$ and $200{ }^{\circ} \mathrm{C}$ for $10,20,30,45$, and $60 \mathrm{~min}$ (see supplementary information in the Appendix, Fig. S1). The pretreatment was carried out with two approaches: one set of pulp side-stream was unwashed, and the other set was washed according to their dry matter (DM) content $(10 \%$ w/v) with $200 \mathrm{~mL}$ of distilled water before dilute acid pretreatment. The most suitable pretreatment indicated in Fig. S1 was ascertained to be $0.2 \% \mathrm{H}_{2} \mathrm{SO}_{4}$ at $180{ }^{\circ} \mathrm{C}$ for $10 \mathrm{~min}$. Both sets of air-dried PI, PII, and PIII side-streams ( $10 \mathrm{~g}$ of dry weight) were pretreated with $0.2 \% \mathrm{H}_{2} \mathrm{SO}_{4}(\mathrm{w} / \mathrm{v})$ at a ratio of 1:10 in a steel cylinder and heated to $180^{\circ} \mathrm{C}$ under a $1 \mathrm{MPa}$ pressure, and the temperature was maintained for $10 \mathrm{~min}$. After the mixture had cooled to room temperature, it was separated using $125 \mathrm{~mm}$ diameter filter paper (Whatman 589/1, Schleicher and Schuell, Little Chalfont, UK). The pretreated liquid hydrolysate was stored at $-20{ }^{\circ} \mathrm{C}$ until the carbohydrates and degradation products were analyzed. The solid fractions from the cylinder and filtrate were washed using $100 \mathrm{~mL}$ deionized water and stored at $-20{ }^{\circ} \mathrm{C}$ for enzymatic hydrolysis. All pretreatments were carried out in duplicate.

\section{Enzymatic hydrolysis}

Enzymatic hydrolysis was performed on four categories for all tested side-streams: (i) original sample (UN), (ii) washed samples without dilute acid pretreatment (W), (iii) unwashed- pretreated sample with dilute sulfuric acid (UWP), and (iv) washed-pretreated sample with dilute sulfuric acid (WP). Enzymatic hydrolysis was performed using a combination of a commercial cellulase preparation (CEL) Celluclast 1.5 L (Sigma-Aldrich, Saint Louis, MO, USA) (10 filter paper units (FPUs)/g of DM), $\beta$-glucosidase (Novozyme 188, Novozymes A/S, Bagsværd, Denmark) (200 nkat/g DM) and endo-1,4-b-xylanase (XYL) from Trichoderma longibrachiatum $(2 \mathrm{~g} / 100 \mathrm{~g} \mathrm{DM})$ after $48 \mathrm{~h}$ of incubation at 50 ${ }^{\circ} \mathrm{C}$ with an agitation speed of $200 \mathrm{rpm}$. After enzymatic hydrolysis, the samples were boiled for $10 \mathrm{~min}$ to stop the hydrolysis process and were then centrifuged at $16128 \mathrm{~g}$ for $10 \mathrm{~min}$. The supernatant was then collected for reducing sugar analysis with the 3.5-dinitrosalicylic acid (DNS) method (Miller 1959). Sugar and acid concentrations were analyzed by nuclear magnetic resonance (NMR). 


\section{Microorganism culture preparation and ABE fermentation}

Freeze-stored $\left(-70{ }^{\circ} \mathrm{C}\right) \quad C$. acetobutylicum DSM 1731 bacteria (DSMZ, Braunschweig, Germany) were activated in $50 \mathrm{~mL}$ of RCM media (Hirsch and Grinsted 1954) at $30{ }^{\circ} \mathrm{C}$ for 14 to $16 \mathrm{~h}$. The inoculum was prepared by transferring $1 \mathrm{~mL}$ of actively growing culture into $50 \mathrm{~mL}$ of a sterilized pre-fermentation P2 medium supplemented with $30 \mathrm{~g} / \mathrm{L}$ of glucose in a $125 \mathrm{~mL}$ screw-capped Pyrex bottle. The P2 medium contained filtersterilized stock solution buffer: $50 \mathrm{~g} / \mathrm{L}$ monopotassium phosphate $\left(\mathrm{KH}_{2} \mathrm{PO}_{4}\right) ; 50 \mathrm{~g} / \mathrm{L}$ dipotassium phosphate $\left(\mathrm{K}_{2} \mathrm{HPO}_{4}\right) ; 220 \mathrm{~g} / \mathrm{L}$ ammonium acetate $\left(\mathrm{NH}_{4} \mathrm{CH}_{3} \mathrm{CO}_{2}\right) ; 20 \mathrm{~g} / \mathrm{L}$ magnesium sulfate heptahydrate $\left(\mathrm{MgSO}_{4} .7 \mathrm{H}_{2} \mathrm{O}\right) ; 1 \mathrm{~g} / \mathrm{L}$ manganese sulfate monohydrate $\left(\mathrm{MnSO}_{4} . \mathrm{H}_{2} \mathrm{O}\right) ; 1 \mathrm{~g} / \mathrm{L}$ ferrous sulfate heptahydrate $\left(\mathrm{FeSO}_{4} .7 \mathrm{H}_{2} \mathrm{O}\right) ; 1 \mathrm{~g} / \mathrm{L}$ sodium chloride $(\mathrm{NaCl}) ; 0.1 \mathrm{~g} / \mathrm{L}$ para-aminobenzoic acid; $0.1 \mathrm{~g} / \mathrm{L}$ thiamin; $0.001 \mathrm{~g} / \mathrm{L}$ biotin, and $10 \mathrm{~g} / \mathrm{L}$ of yeast extract (Yang et al. 2015). The culture was anaerobically incubated for $16 \mathrm{~h}$ at $37{ }^{\circ} \mathrm{C}$ before inoculation into ABE fermentation media. All experiments were done in duplicate.

Batch fermentations of all tested pulp side-steams were carried out in $100 \mathrm{~mL}$ serum bottles with $30 \mathrm{~mL}$ working volume that contained a mixture of P2 medium, RCM and enzymatic hydrolysate of the pulp side-steams. The initial $\mathrm{pH}$ of the fermentation broth was adjusted to 6.5 with calcium hydroxide before fermentation. The fermentation bottle was purged with nitrogen $(\mathrm{N})$ gas for $10 \mathrm{~min}$ and crimp-sealed with a rubber stopper to maintain anaerobic conditions. The bottles were then autoclaved at $121{ }^{\circ} \mathrm{C}$ for $15 \mathrm{~min}$. The $\mathrm{ABE}$ fermentation was started by inoculating the samples with $2 \mathrm{~mL}$ of $C$. acetobutylicum DSM 1731 culture. All the experiments were conducted in duplicate under strict anaerobic conditions. Aliquots $(2 \mu \mathrm{L})$ of fermentation samples were taken at $0,24,48,72$, and $96 \mathrm{~h}$ after inoculation.

\section{Chemical analyses}

Determination of the DM and ash contents of the side-streams was carried out according to the National Renewable Energy Laboratory (NREL) standard procedure (Sluiter et al. 2008a,b). The organic matter content, as measured by loss-on-ignition (LOI), was determined according to Kuokkanen et al. (2008). Total nutrients and heavy metal concentrations in the tested samples were determined by an inductively coupled plasma optical emission spectrometer (ICP-OES), model ICP-OES-IRIS Intrepid II XSP (Thermo Fisher Scientific, Waltham, MA, USA). Two reagents (concentrated 65\% w/w nitric acid $\left(\mathrm{HNO}_{3}\right)$ and $30 \%$ hydrogen peroxide $\left(\mathrm{H}_{2} \mathrm{O}_{2}\right)$ were used in the preparation of the elemental samples. The dried samples were digested with $10 \mathrm{~mL}$ of concentrated $\mathrm{HNO}_{3}$ and analyzed with a CEM Mars 5 microwave at $175^{\circ} \mathrm{C}$ for $10 \mathrm{~min}$. Total $\mathrm{N}$ concentration in the tested samples was measured by the Kjeldahl method (Kjeldahl 1883).

The chemical composition of the solid pulp samples was determined according to Hayes (2012). Liquid samples before and after pretreatment, enzyme hydrolysis and ABE fermentation were analyzed by proton nuclear magnetic resonance ( ${ }^{1} \mathrm{H}$ NMR) spectroscopy for the solvents (acetone, butanol, ethanol), sugars (glucose, xylose, and arabinose), and other compounds (furfural, 5-hydroxymethylfurfural - HMF, formic acid, acetic acid, butyric acid, and lactic acid) (Yang et al. 2015). The original side-stream samples were first centrifuged at $5000 \mathrm{~g}$ for $10 \mathrm{~min}$ before the supernatant was sent for NMR analysis. The NMR spectra for quantification of these compounds were recorded on a $600 \mathrm{MHz}$ Bruker NMR spectrometer, equipped with a CryoProbe ${ }^{\mathrm{TM}}$ (Bruker Prodigy TCI 600 S3 H\&F-C/N-D-05 Z, Ettlingen, Germany) and an automatic cooled SampleJet robotic sample changer. These compounds were identified from routine two-dimensional proton-proton and proton-carbon correlated spectra. Prior to the NMR measurements, $200 \mu \mathrm{L}$ of the 
sample liquid was transferred to a $5 \mathrm{~mm}$ NMR tube, followed by addition of deuterium oxide $\left(\mathrm{D}_{2} \mathrm{O}, 275 \mu \mathrm{L}\right)$ and 3-(trimethylsilyl)-propionic - $\mathrm{d}_{4}$ acid $(25 \mu \mathrm{L}, 20 \mathrm{mM})$ in $\mathrm{D}_{2} \mathrm{O}$ as an internal standard of known concentration.

\section{RESULTS AND DISCUSSION}

\section{Characterization of the Pulp and Paper Manufacturing Process Side-streams}

The physical appearances of PI, PII, and PIII conformed with their process stages, i.e., the dark brown color of PI was from the residue of pre-hydrolysis before kraft dissolving pulp, whereas PII's dark tone was from the waste stream of physical treatment after cooking, delignification, and dewatering, and the brown color of PIII was from the waste stream of biological treatment (Fig. 1). The PI sample was noticeably more basic $(\mathrm{pH}$ 10.1) than the PII ( $\mathrm{pH} 7.3)$ and PIII ( $\mathrm{pH}$ 7.4) samples (Table 2). This is reasonable because causticizing reagents are used in the pulping process, and the secondary sludge (PIII) is generated from a wastewater treatment process where the $\mathrm{pH}$ is nearly neutral before the wastewater is discharged to water bodies. The moisture contents of the PI, PII, and III samples were $77.3,75.8$, and $87.7 \%$, respectively, which conforms to values for pulp mill primary sludge 67 to $77.1 \%$ (Simão et al. 2018). The high moisture content in the studied samples indicates that the incineration of these side-streams, as such, did not create any net energy (Pöykiö et al. 2018). The organic matter content, measured as LOI, was slightly greater in the PI sample compared to the PII and PIII samples (Table 2). The very high LOI values in these samples are also reasonable because these samples are still rich in cellulose, hemicellulose, and lignin, as well as the organic binders that originate from the pulping process (Pöykiö et al. 2018). As shown in Table 2, the ash content of PI $(5.19 \%)$ was lower than PII (7.08\%) and PIII (7.11\%), but all our samples are comparable to the $6 \%$ ash content reported for generated paper mill waste by Méndez et al. (2009).

Table 2. Physical and Chemical Properties of the Studied Pulp and Paper Manufacturing Process Side-streams

\begin{tabular}{|c|c|c|c|}
\hline Property and Component & PI & PII & PIII \\
\hline pH & 10.1 & 7.3 & 7.4 \\
\hline Moisture content (\%) & 77.30 & 75.80 & 87.70 \\
\hline & \multicolumn{3}{|c|}{ (\% dry basis) } \\
\hline Lost-on-ignition (LOI) & 94.81 & 92.92 & 92.89 \\
\hline Glucan & 56.54 & 43.72 & 39.16 \\
\hline Xylan & 6.82 & 4.01 & 6.26 \\
\hline Mannan & 5.52 & 2.67 & 8.17 \\
\hline Arabinan & 0.90 & 0.58 & 0.89 \\
\hline Galactan & 1.11 & 0.99 & 1.71 \\
\hline Rahmnan & 0.03 & 0.34 & 0.29 \\
\hline Total sugars & 70.91 & 52.32 & 56.48 \\
\hline Klason lignin & 19.10 & 19.15 & 24.87 \\
\hline Acid soluble lignin (ASL) & 0.51 & 2.63 & 0.81 \\
\hline Ash & 5.19 & 7.08 & 7.11 \\
\hline Extractives & 7.50 & 10.05 & 7.71 \\
\hline $\begin{array}{l}\text { Results of Klason lignin, ASL, extractives, and structural carbohydrates were } \\
\text { measured according to Hayes (2012). }\end{array}$ \\
\hline \multicolumn{2}{|l}{} \\
\hline \multicolumn{2}{|c|}{}
\end{tabular}


The manufacturing processes in the pulp and paper industry produce variable amounts of side-streams and waste, e.g. primary and secondary sludges, all inherently different in their composition. Primary sludge (PII in the present study) and secondary wastewater treatment sludge (PIII in the present study) are rich in both organic and inorganic contents (Bajpai 2015; Gottumukkala et al. 2016). In contrast, the PI sample in this study is the reject from the pre-hydrolysis stage of the kraft pulping, in which the content of extractives (7.5\%) was lower than in PII (10.05\%) and PIII (7.71\%) (Table 2). The previous studies reported that solid waste from softwood pulp mills contained high levels of wood extractives; however, pre-hydrolysis pulping removed $50 \%$ of extractives (Wegner et al. 2012), while the primary sludge adsorbed only 3.9 to $14 \%$ of the extractives at primary clarifier. By contrast, the reduction of extractives was over $90 \%$ in the pulp and paper mill effluents of all studied wastewater treatment plants (Kostamo et al. 2004).

In general, a side-stream such as PI is recycled back to the main stream for refining (Gavrilescu 2008). Furthermore, the chemical composition of the pulp and paper manufacturing process side-streams vary considerably from one industrial plant to another, depending on the wastewater cleaning technique applied, fresh water consumption, and the type of raw materials (Kuokkanen et al. 2008). Among our samples, PI exhibited the greatest sugar content; $63.3 \%$ (glucan $56.5 \%$ and xylan $6.8 \%$ ), and the lowest lignin $(19.1 \%)$ content (See PI in Table 2), which is in agreement with the sugar and lignin contents reported by Guan et al. (2016) and Gogoi et al. (2018) for paper mill sludge (64.4\% and $16 \%$, respectively). The sugar contents of PII (47.7\%: glucan $43.7 \%$ and xylan 4\%) and PIII (45.4\%: glucan 39.2\% and xylan 6. 2\%) (Table 2) are similar to those found in primary sludge (glucan $44.5 \%$ and xylan $9.9 \%$ ) and recycled sludge from kraft paper mills (glucan 49.6\% and 13.7\%) (Kang et al. 2010). However, Gottumukkala et al. (2016) reported that the carbohydrate content of paper sludge can vary considerably (between $20 \%$ and $75 \%)$.

The supernatant derived from the original PI, PII, and PIII samples after centrifugation also contained weak organic acids and alcohols, such as acetic acid, formic acid, glycerol, and methanol (Fig. 2). The centrifuged supernatant from PI had the greatest total sugar content $\left(25.63 \mathrm{mg} \mathrm{g}^{-1}\right)$, while PII contained approximately $50 \%$ of the sugar content (12.65 $\mathrm{mg} \mathrm{g}^{-1}$ ) observed in PI (see PI and PII in Fig. 2). In contrast, the centrifuged supernatant PIII sample did not contain free sugars. Glycerol, methanol, acetic acid, and lactic acid were found in all tested samples, whereas PI and PIII contained exclusively formic and propionic acids. The high glycerol contents found in all tested samples can originate from lipids in the manufacturing process. A previous study reported that biochemical compounds, such as proteins, carbohydrates, lipids, and inorganics are found in the activated sludge from the biological process in pulp and paper wastewater treatments (Rozich and Gaudy 1992).

Determination of inorganic compounds in the pulp and paper manufacturing process side-streams is important because they are indicative of the total and leachable trace element concentrations for the wastewater treatment plant (Kuokkanen et al. 2008). Also, the high concentration of a dominant inorganic component, $\mathrm{CaCO}_{3}$, in the paper sludge, can affect the enzymatic hydrolysis and cause viscosity issues at high solid loadings, but can benefit the butanol production and fermentation process (Yang et al. 2013, Gottumukkala et al. 2016). 


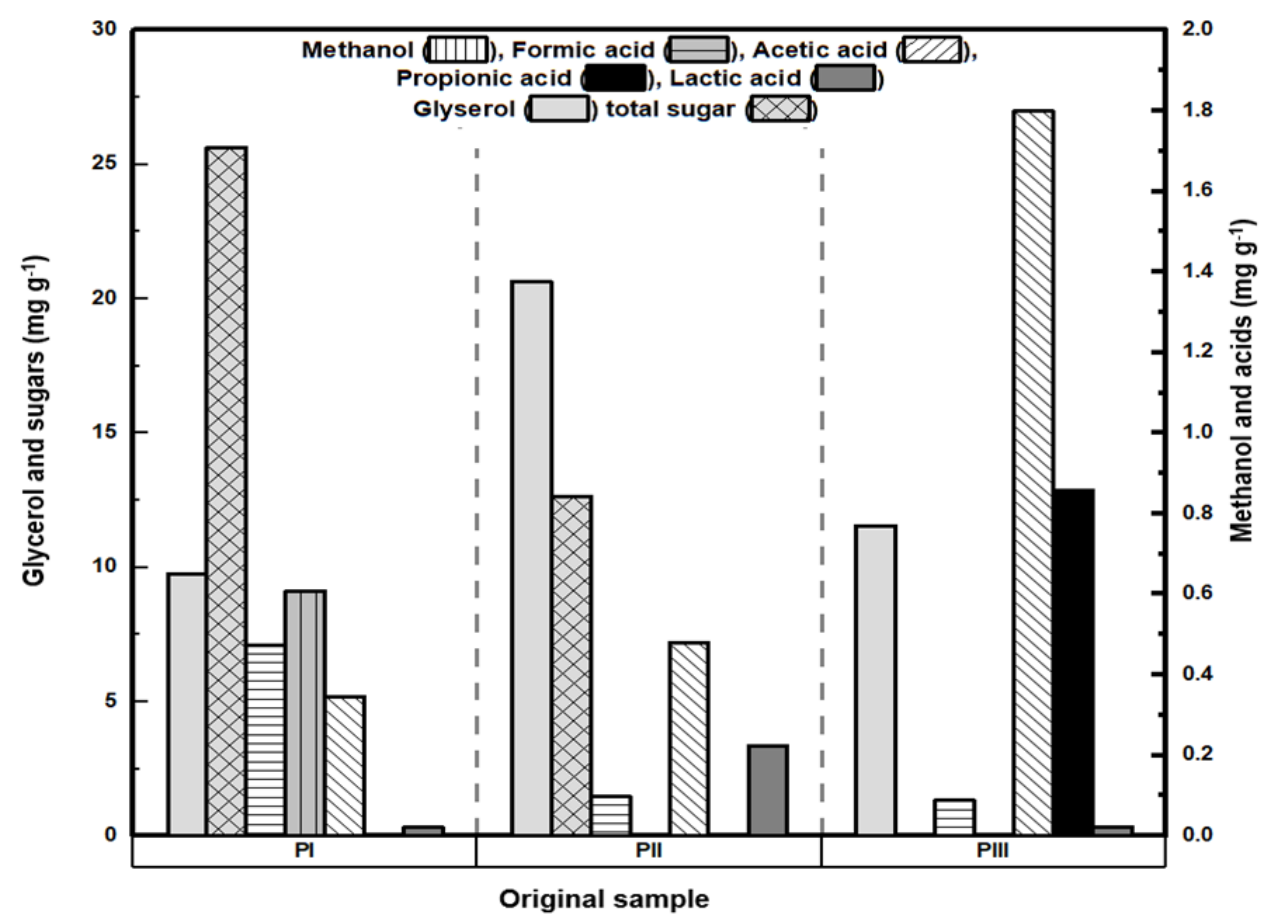

Fig. 2. Chemical content of the supernatant from the original pulp and paper manufacturing process side-streams

The major organic components in paper sludge are cellulose fiber, lignin, and organic binders, while the main inorganic components are paper additives such as kaolinite (clay) and $\mathrm{CaCO}_{3}$ as well as heavy metals from the wood raw material (Kuokkanen et al. 2008). For example, kraft process side-streams such as lime mud, grits, and dregs contain calcium $(\mathrm{Ca})$ as the predominant ion, together with barium $(\mathrm{Ba})$, chromium $(\mathrm{Cr})$, copper $(\mathrm{Cu})$, lead $(\mathrm{Pb})$, nickel $(\mathrm{Ni})$ and zinc $(\mathrm{Zn})$ in grits, magnesium $(\mathrm{Mg})$, potassium $(\mathrm{K})$, sodium $(\mathrm{Na}), \mathrm{Cr}$, manganese $(\mathrm{Mn})$ and iron $(\mathrm{Fe})$ trace elements in lime mud, and substantial amounts of $\mathrm{Na}, \mathrm{K}, \mathrm{Mn}, \mathrm{Mg}$, and $\mathrm{Zn}$ in the dregs (Simão et al. 2018). In this study, the primary $(\mathrm{N}$, phosphorus $(\mathrm{P})$, and $\mathrm{K})$ and secondary plant nutrients $(\mathrm{Ca}, \mathrm{Mg}$, and sulfur $(\mathrm{S}))$, and trace element concentrations (e.g. arsenic (As), boron (B), $\mathrm{Cu}, \mathrm{Mn}, \mathrm{Fe}$, molybdenum (Mo), cadmium (Cd), cobalt $(\mathrm{Co}), \mathrm{Cr}, \mathrm{Ni}, \mathrm{Pb}$, titanium (Ti) and vanadium (V)) were compared with those recorded from paper mill sludge from the Stora Enso Oyj paper mill (in Oulu) and with pulp sludge from a wastewater treatment plant of the Finnish kraft pulp and linerboard mill (Table 3). The concentrations of Na and S in the PI and PII samples were high because they were collected from the kraft pulping sulfate process, and $\mathrm{Na}$, in the forms of sodium sulfide $\left(\mathrm{Na}_{2} \mathrm{~S}\right)$, sodium hydroxide $(\mathrm{NaOH})$ and sodium sulfate $\left(\mathrm{Na}_{2} \mathrm{SO}_{4}\right)$, is present in cooking chemicals (Table 3 ). The PIII samples had the highest $\mathrm{Ca}$ content (18471 mg kg${ }^{-1}$ ) compared to the PI (1386 mg kg${ }^{-1}$ ) and PII (7471 mg kg-1) samples (Table 3). This was much lower in comparison to the Ca content recorded in the paper mill sludge from the Stora Enso Oyj paper mill (194000 $\left.\mathrm{mg} \mathrm{kg}^{-1}\right)$, and from secondary sludge in a wastewater treatment plant in Finland $\left(34900 \mathrm{mg} \mathrm{kg}^{-1}\right)$, because $\mathrm{Ca}$ is the most abundant mineral in wood (Kuokkanen et al. 2008; Pöykiö et al. 2018).

The PI samples exhibited lower inorganic element concentrations compared to the PII and PIII samples, with the exception of $\mathrm{Na}$ and $\mathrm{K}$. A previous study reported that primary sludge is composed of small amounts of $\mathrm{K}, \mathrm{Mg}, \mathrm{Na}$ and several toxic metals, and exhibits high $\mathrm{C}: \mathrm{N}$ ratios (150 to 250 ), while secondary sludge, in contrast, has a low $\mathrm{C}: \mathrm{N}$ 
ratio (5 to 30) (Simão et al. 2018). Furthermore, the heavy metal concentrations (As, Cd, $\mathrm{Cr}, \mathrm{Cu}, \mathrm{Hg}, \mathrm{Ni}, \mathrm{Pb}, \mathrm{Zn}$ ) in the PI and PIII samples were lower than the maximum permissible content for Finnish fertilizer products (MMM (24/2011) 2013). However, the Cd concentration $\left(3 \mathrm{mg} \mathrm{kg}^{-1}\right)$ in the PII samples exceeded the $1.5 \mathrm{mg} \mathrm{kg}^{-1}$ limit for Finnish fertilizer products, and elevated $\mathrm{N}$ and $\mathrm{P}$ concentrations were also found in the PII samples. Most probably, the collected PII sample is a primary sludge from the final process of kraft pulping, where nutrients, such as $\mathrm{N}$ and $\mathrm{P}$, dissolved organic compounds and colloidal particles are still in the residue (Pöykiö et al. 2018). The authors suggest that PI could be a potential feedstock for butanol production due to its high sugar, low lignin, and low ash contents.

Table 3. Comparison of Element Contents between the Studied Pulp and Paper Manufacturing Process Side-streams and Pulp and Paper Mill Sludge from Other Finnish Pulp and Paper and Board Industry

\begin{tabular}{|c|c|c|c|c|c|c|}
\hline \multirow[t]{3}{*}{ Elements } & \multicolumn{3}{|c|}{$\begin{array}{l}\text { In this study: Finnish } \\
\text { Pulp Mills (Kraft and } \\
\text { Mechanical Pulping } \\
\text { Processes) }\end{array}$} & \multirow[t]{2}{*}{\begin{tabular}{|c|}
$\begin{array}{c}\text { Stora Enso } \\
\text { Oyj, Oulu Mill, } \\
\text { Finland A }\end{array}$ \\
$\mathrm{mg} \mathrm{kq}^{-1}$ (dry matt
\end{tabular}} & \multicolumn{2}{|c|}{$\begin{array}{c}\text { Wastewater Treatment Plant } \\
\text { of Finnish Kraft Pulping and } \\
\text { Linerboard Mill B }\end{array}$} \\
\hline & & & & & & \\
\hline & $\mathrm{Pl}$ & PII & PIII & $\begin{array}{l}\text { Paper mill } \\
\text { sludge }\end{array}$ & $\begin{array}{l}\text { Primary } \\
\text { sludge }\end{array}$ & $\begin{array}{l}\text { Secondary } \\
\text { sludge }\end{array}$ \\
\hline Aluminium, $\mathbf{A l}$ & $<\mathrm{LQD}$ & 2558 & 3081 & NA & 1910 & 8940 \\
\hline Arsenic, As & $<\mathrm{LQD}$ & $<L Q D$ & $<L Q D$ & $<2.0$ & $<3.0$ & 4.6 \\
\hline Boron, B & $<\mathrm{LQD}$ & 13 & $<$ LQD & NA & $<4.0$ & 68 \\
\hline Calcium, Ca & 1386 & 7471 & 18471 & 194000 & 4970 & 34900 \\
\hline Cadmium, Cd & 0 & 3 & 0 & 0.3 & 0.5 & 4.8 \\
\hline Cobalt, Co & $<\mathrm{LQD}$ & 1 & 0 & $<1.0$ & $<1.0$ & 2.8 \\
\hline Chromium, $\mathrm{Cr}$ & 8 & 75 & 32 & 8.0 & 19 & 49 \\
\hline Copper, $\mathrm{Cu}$ & 1 & 12 & 16 & 6.5 & 6.3 & 20 \\
\hline Iron, Fe & 52 & 3611 & 1065 & 850.0 & 1930 & 6280 \\
\hline Mercury, $\mathrm{Hg}$ & $<\mathrm{LQD}$ & $<L Q D$ & $<$ LQD & NA & $<0.04$ & $<0.04$ \\
\hline Potassium, K & 1456 & 886 & 299 & 120.0 & $<200$ & 2490 \\
\hline Lithium, Li & $<\mathrm{LQD}$ & $<L Q D$ & $<L Q D$ & NA & NA & NA \\
\hline Magnesium, Mg & 0.32 & 0.85 & 1.22 & 1300 & 540 & 3830 \\
\hline Manganese, $\mathrm{Mn}$ & 128 & 1242 & 35 & 54.6 & 79.0 & 6330 \\
\hline $\begin{array}{c}\text { Molybdenum, } \\
\text { Mo }\end{array}$ & $<L Q D$ & 1 & $<L Q D$ & NA & $<1.0$ & 4.7 \\
\hline Sodium, $\mathrm{Na}$ & 13145 & 1940 & 502 & 360.0 & 550 & 13500 \\
\hline Nickel, Ni & 3 & 7 & 5 & 3.0 & 8.6 & 32 \\
\hline Phosphorus, P & 21 & 2351 & 674 & 79.0 & 320 & 5660 \\
\hline Lead, $\mathrm{Pb}$ & 1 & 5 & 2 & 6.5 & $<3.0$ & 6.0 \\
\hline Sulphur, S & 3490 & 6411 & 1296 & 530.0 & 2730 & 20100 \\
\hline Antimony, Sb & $<\mathrm{LQD}$ & $<L Q D$ & $<L Q D$ & NA & $<3.0$ & $<3.0$ \\
\hline Selenium, Se & $<\mathrm{LQD}$ & $<L Q D$ & $<L Q D$ & NA & $<3.0$ & $<3.0$ \\
\hline Silicon, Si & 54 & 573 & 513 & NA & NA & NA \\
\hline Titanium, Ti & $<\mathrm{LQD}$ & 44 & 6 & 461.0 & 53 & 90 \\
\hline Vanadium, V & 7 & 19 & 7 & $<1.0$ & NA & NA \\
\hline Tungsten, W & $<\mathrm{LQD}$ & $<L Q D$ & $<$ LQD & NA & NA & NA \\
\hline Zinc, $\mathrm{Zn}$ & 17 & 247 & 16 & 11.9 & 110 & 490 \\
\hline $\mathbf{N}$ & 1000 & 26000 & 6000 & NA & 4000 & 42600 \\
\hline
\end{tabular}




\section{Sugar Extraction with Dilute Sulfuric Acid Pretreatment}

In this study, washed and non-washed steps were performed prior to dilute acid pretreatment $\left(0.2 \% \mathrm{H}_{2} \mathrm{SO}_{4}\right.$ at $180{ }^{\circ} \mathrm{C}$ for $\left.10 \mathrm{~min}\right)$ as alternative approaches to determine whether the studied side-steams require a prewashing step to increase pretreatment efficiency. Water washing and de-ashing are usually applied to remove ash, clay, $\mathrm{CaCO}_{3}$, impurities, and cooking chemical residues from the pulping process, in order to increase the pretreatment and hydrolysis yield for bioethanol and biobutanol production (He et al. 2014; Guan et al. 2016; Huang et al. 2016).

The $\mathrm{pH}$ values of the PII and PIII samples were almost similar in the washed and unwashed samples before $0.2 \% \mathrm{H}_{2} \mathrm{SO}_{4}$ pretreatment, and were close to the mean $\mathrm{pH}(7.09)$ of paper mill sludge (Abdullah et al. 2015). Both PI and PII side-streams were collected from the kraft pulping process (using $\mathrm{NaOH}$ and $\mathrm{Na}_{2} \mathrm{~S}$ ), but nevertheless, the $\mathrm{pH}$ of the unwashed PI was strongly alkaline ( $\mathrm{pH}$ 10.1) (Table 4). However, the $\mathrm{pH}$ was the same as the values recorded in wastewater generated from a kraft mill (Ashrafi et al. 2015). The high $\mathrm{pH}$ of paper mill sludge is caused by the presence of causticizing reagents used in the pulping process and/or $\mathrm{CaCO}_{3}$ used in the paper finishing process (Abdullah et al. 2015). The change in $\mathrm{pH}$ values in the unwashed PI, PII, and PIII samples (4.9, 4.8, and 4.6, respectively) after dilute acid pretreatment, compared to the original $\mathrm{pH}$ of these samples before acid pretreatment (10.1, 7.3, and 7.4, respectively) was presumably indicative of neutralization of the samples, rather than a pretreatment effect on the tested side-stream materials.

A key advantage of the pulp and paper manufacturing process side-streams is that the crystalline structure of cellulose has been disrupted during the papermaking process, which enhances enzymatic hydrolysis. However, there are several inherent disadvantages. For example, an ash content of $>50 \%$ in paper mill sludge harms enzyme hydrolysis as it interferes with pH control (Kang et al. 2010; Boshoff et al. 2016). Ash in paper mill sludge is composed of inorganic salts, of which $\mathrm{CaCO}_{3}$ is the predominant component. The $\mathrm{CaCO}_{3}$ can dramatically increase the $\mathrm{pH}$ of the pulp sludge suspension in water or buffer solution. Therefore, ash in paper sludge should be removed by washing in order to improve glucan digestibility (Guan et al. 2016). The ash contents in our PI, PII, and PIII samples were slightly reduced (to $2.25 \%, 6.18 \%$, and $6.75 \%$, respectively) after a one-cycle water wash. A previous study discovered that the ash content of unwashed kraft paper mill sludge could be as high as $32.7 \%$, although, the ash content was observed to decrease to $25.1 \%$ and $6.1 \%$, and the glucan content was observed to increase to $55.5 \%$ and $71.8 \%$, after two and seven cycles of water washing, respectively (Guan et al. 2016). However, some studies suggest that the high ash content in pulp and paper sludge can play a positive role in $\mathrm{ABE}$ fermentation; Clostridia evinced increased sugar utilization to produce higher butanol yields in the presence of $\mathrm{CaCO}_{3}$ in pulp mill sludge (Yang et al. 2013; Gottumukkala et al. 2016).

The prehydrolysate from wood is a very complicated mixture of different sugars that cannot be simulated just by pure glucose; for example, hemicellulose sugars and lignin can be obtained either in the liquid or remain in the solid part that has the potential to be used for high-value products (Galbe and Zacchi 2007; Karimi et al. 2015). However, the prehydrolysate of the studied samples was different from that of wood, as they had already experienced pretreatment under the pulping processes. Furthermore, this study only focused on the cellulosic sugars left in the pulping processes side-streams. Table 4 represented that the prehydrolysate of the PI unwashed sample (330 $\left.\mathrm{mg} \mathrm{g}^{-1}\right)$ contained an elevated amount of reducing sugars compared to the washed sample $\left(242.5 \mathrm{mg} \mathrm{g}^{-1}\right)$, 
whereas the opposite situation was found in the PII and PIII samples. In practice, sugars were not found in either the unwashed samples or in the washed prehydrolysate PII and PIII liquid samples. Thus, it would seem that dilute acid pretreatment does not convert hemicellulose to monomeric sugars. Instead, inhibitory compounds, such as furfural and $\mathrm{HMF}$, are formed. This finding is reasonable because dilute $\mathrm{H}_{2} \mathrm{SO}_{4}$ is usually mixed with biomass to hydrolyze hemicellulose and to continuously break down xylose and other sugars to form furfural (Kumar et al. 2009). However, the washed prehydrolysate PI liquid sample contained monosaccharide sugars $\left(0.04 \mathrm{mg} \mathrm{g}^{-1}\right.$ glucose, $10.75 \mathrm{mg} \mathrm{g}^{-1}$ xylose, 5.07 $\mathrm{mg} \mathrm{g}^{-1}$ arabinose, and $0.17 \mathrm{mg} \mathrm{g}^{-1}$ mannose) after dilute acid pretreatment (Table 4).

Table 4. Comparison of Composition and $\mathrm{pH}$ values of the Liquid Prehydrolysate of Unwashed and Washed PI, PII, and PIII Before and After Dilute Acid Pretreatment $\left(0.2 \% \mathrm{H}_{2} \mathrm{SO}_{4}\right.$ at $180{ }^{\circ} \mathrm{C}$ for $\left.10 \mathrm{~min}\right)$

\begin{tabular}{|c|c|c|c|c|c|c|}
\hline & \multicolumn{3}{|c|}{$\begin{array}{c}\text { Unwashed prior to Acid } \\
\text { Pretreatment }\end{array}$} & \multicolumn{3}{c|}{$\begin{array}{c}\text { Washed prior to Acid } \\
\text { Pretreatment }\end{array}$} \\
\hline & PI & PII & PIII & PI & PII & PIII \\
\hline pH before pretreatment & 10.1 & 7.3 & 7.4 & 7.4 & 6.9 & 7.2 \\
\hline pH after pretreatment & 4.9 & 4.8 & 4.6 & 5.6 & 4.3 & 4.6 \\
\hline $\begin{array}{c}\text { Sugars, furans and acids } \\
\text { in liquid prehydrolysate }\end{array}$ & & & & & & \\
\hline Reducing sugars & 330.0 & 127.5 & 35.0 & 242.5 & 153.8 & 129.2 \\
\hline & & & $\left.\left(\mathrm{mg} \mathrm{g} \mathrm{g}^{-1}\right)^{*}\right)^{* *}$ & & & \\
\hline Glucose & 0.00 & 0.00 & 0.00 & 0.04 & 0.00 & 0.00 \\
\hline Xylose & 0.00 & 0.00 & 0.00 & 10.75 & 0.00 & 0.00 \\
\hline Arabinose & 0.00 & 0.00 & 0.00 & 5.07 & 0.00 & 0.00 \\
\hline Mannose & 0.00 & 0.00 & 0.00 & 0.17 & 0.00 & 0.00 \\
\hline Furfural & 0.87 & 0.62 & 0.44 & 1.36 & 1.05 & 0.52 \\
\hline HMF & 0.10 & 0.70 & 0.16 & 0.28 & 1.15 & 0.19 \\
\hline Formic acid & 3.28 & 0.00 & 1.37 & 1.87 & 1.34 & 1.34 \\
\hline Acetic acid & 1.08 & 0.00 & 5.65 & 0.00 & 0.00 & 2.38 \\
\hline * Results measured by DNS method (Miller 1959$) ; * *$ Results measured by NMR \\
\hline
\end{tabular}

Previous studies reported that hemicellulose fractions (termed as prehydrolysate) of pine chips containing a large amount of mannose oligomers were mixed with kraft pulp mill sludge for the production of lactic acid and ethanol (Kang et al. 2012; Shi et al. 2015). Mendes et al. (2014) studied the conversion of a residual stream of primary sludge to bioethanol, in which $\mathrm{CaCO}_{3}$ neutralization pretreatment was performed with water, spent acid from the mill, carbonated water, and different organic and inorganic acids. To our knowledge, the previous researchers did not analyze the sugar contents in the prehydrolysate of pulp and paper mill sludges. Probably, the hemicellulose fraction in the kraft pulping process is released into black liquor, which is combusted to recover chemicals and to generate energy. On the other hand, kraft pulping is the best-suited pretreatment for softwoods; however, the various pretreatment methods give different types of products. The studied samples are the processed lignocellulosic biomass in kraft pulping and mechanical pulping. Notably, they do not require chemical pretreatment, detoxification, and $\mathrm{pH}$ control (Guan et al. 2016). Worldwide, kraft pulping is the dominating process for producing chemical pulp due to the properties of its pulp fibers to produce paper, board, 
dissolving pulp, and other applications. However, the properties of pulps depend not only on wood material but also on the pulping process, the extent of delignification, and the bleaching sequences (Rahman et al. 2017). In kraft cooking, two types of carbohydrate reaction occur: a peeling and an alkaline pretreatment, in which the latter one tends to have a marked effect on lignin due to disruption of ester bonds between lignin and xylan, some removal of hemicellulose, and changes to the less crystalline solid residue of cellulose (Saville 2011). The previous research found that the hot-water extraction could extract approximately $15 \%$ of the chip mass and remove a significant amount of xylan from the chips, or kraft cooking time can be reduced from $120 \mathrm{~min}$ to $<30 \mathrm{~min}$ at $165{ }^{\circ} \mathrm{C}$ (Amidon et al. 2008). The studied sample PI has a high expectation of having the best ABE yield due to its original process stage, which involved autohydrolysis.

\section{Enzymatic Hydrolysis of Untreated and Pretreated Side-streams}

Enzymatic digestion of lignocellulosic materials requires suitable DM loading, which involves the synergistic interaction of a group of different enzymes: endoglucanases and cellobiohydrolases, as well as a variety of other enzymes, including xylanases and mannanases. In this study, the side-streams were subjected to washing and non-washing before dilute acid pretreatment and enzymatic hydrolysis. Therefore, the unwashed and washed PI samples were preliminarily hydrolyzed with different DM loadings, and with different enzymes (see supplementary, Fig. S2A, S2B, and S2C).

All side-streams (PI, PII, and PIII) were proceeded by $7 \%$ DM loading with a $\mathrm{CEL}+\mathrm{XYL}$ enzyme combination. Enzymatic hydrolysis was conducted under four types of reaction conditions: (i) untreated (UN) as a control, (ii) washed only (without dilute acid pretreatment) (W), (iii) unwashed- pretreated sample with dilute sulfuric acid (UWP), and (iv) washed-pretreated sample with dilute sulfuric acid (WP). According to the results of the 48-h enzymatic hydrolysis, all the raw pulp side-streams in this study could produce sugars without acid pretreatment. However, the sugar concentration was found to be higher after dilute acid pretreatment in all raw samples.

The PI hydrolysate exhibited lower glucose yields in both the UN and W reactions, compared to UWP and WP, prior to pretreatment with $0.2 \% \mathrm{H}_{2} \mathrm{SO}_{4}$. The glucose differences are illustrated in Fig. 3A, which shows that the highest glucose yield $(0.68 \mathrm{~g} / \mathrm{g})$ for PI was achieved in UWP, whereas WP yielded the highest glucose concentration $(0.50$ $\mathrm{g} / \mathrm{g}$ ) in PII. Dilute acid pretreatment was required for PIII, as glucose concentrations in UN and $\mathrm{W}$ were $0.011 \mathrm{~g} / \mathrm{g}$ and $0.004 \mathrm{~g} / \mathrm{g}$, respectively, whereas glucose concentrations in the UWP and WP samples were $0.28 \mathrm{~g} / \mathrm{g}$ and $0.29 \mathrm{~g} / \mathrm{g}$, respectively, as represented by the right part of Fig. 3A.

As shown in Fig. 3B, all PI hydrolysates contained only acetic acid, while lactic acid and acetic acid were found in the control (UN) PII and PIII samples and in the washed (W) PII and PIII samples. Propionic acid was found in the UN and W PIII samples. Moreover, the untreated (UN) PIII sample contained less sugars and generated more lactic acid $(0.19 \mathrm{~g} / \mathrm{g})$ (see Fig. 3B). Furthermore, propionic acid was only found in the supernatant of the original PIII sample and in the enzymatic hydrolyzed PIII sample (see Fig. 2 and Fig. 3B).

The UWP PI sample $(0.68 \mathrm{~g} / \mathrm{g})$ had a greater sugar concentration than the WP PI sample $(0.57 \mathrm{~g} / \mathrm{g})$, which showed that prewashing was not needed for the PI samples. This result indicates that enzymatic hydrolysis seemed to work better in the unwashed PI samples because prewashing can remove soluble carbohydrates and, consequently, decrease the sugar yield. 

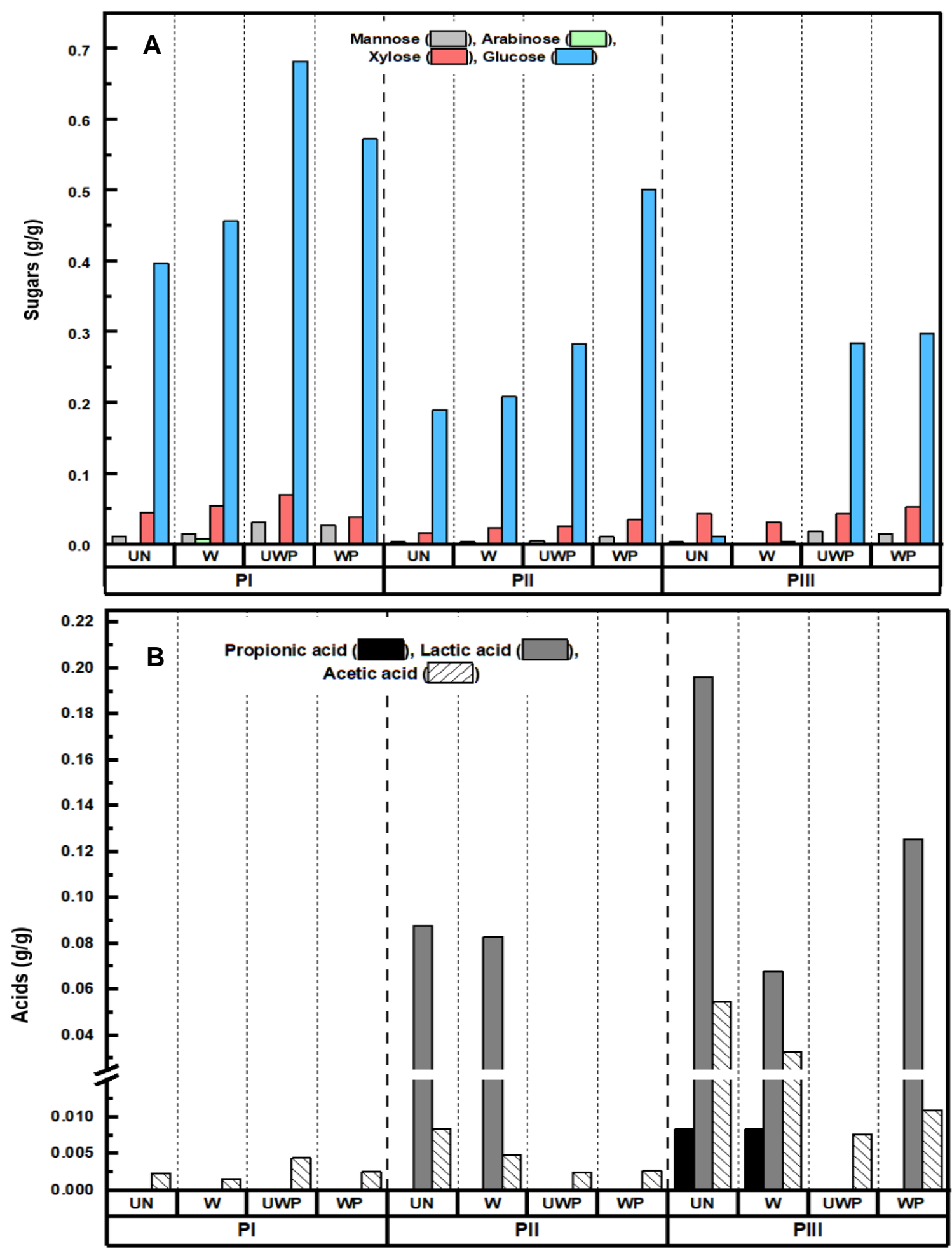

Untreated and pretreated pulp side-streams after $48 \mathrm{~h}$ enzymatic hydrolysis

Fig. 3. Enzymatic hydrolysis of pulp and paper manufacturing side-streams, PI, PII and PIII: untreated as control (UN), washed without dilute acid pretreatment (W), unwashed (UWP) and washed (WP) prior to pretreatment with $0.2 \% \mathrm{H}_{2} \mathrm{SO}_{4}$ at $180^{\circ} \mathrm{C}$ for $10 \mathrm{~min}$. (A) Sugars concentration, (B) Acids concentrations 
It can be concluded that enzyme hydrolysis of a pulp side-stream such as PI, does not require prewashing, and that all the tested samples in this study displayed better results with dilute acid pretreatment, especially sample PIII.

\section{ABE Fermentation from Pulp and Paper Manufacturing Process Side- streams}

The unwashed hydrolyzed (UWP) PI, PII, and PIII samples were selected for all the $\mathrm{ABE}$ fermentations conducted in this study, and slurries were supplemented with 30 $\mathrm{g} / \mathrm{L}$ of glucose, minerals, and vitamins for microbial growth. In ABE fermentation, glucose is more preferable than other reducing sugars because of the higher efficiency in sugarspecific mechanisms, including transcriptional regulation of transport, and the number of metabolism genes is far higher than in other carbon sources (Jiang et al. 2014). The addition of glucose to the lignocellulosic hydrolysate is a common practice to increase the total and individual sugar concentrations in the fermentation medium.

In this study, a similar concentration of glucose was added to the hydrolyzed samples, although the original reducing sugar contents of PI, PII, and PIII were different $(65.8 \mathrm{~g} / \mathrm{L}, 33.5 \mathrm{~g} / \mathrm{L}$, and $38.5 \mathrm{~g} / \mathrm{L}$, respectively). The aim was to investigate the fermentability of the pulp and paper manufacturing process side-streams by glucose uptake at different concentrations.

ABE fermentation by $C$. acetobutylicum can be divided into biphasic stages: acidogenesis (rapid cell growth and an acid production stage), and solventogenesis (solvent production stage, in which the produced acids are consumed by the cells) (Yang et al. 2013; Jiang et al. 2014). These stages are significantly affected by $\mathrm{pH}$, and by the intra- and extracellular environment (Maddox et al. 2000; Yang et al. 2013). Normally, acid production starts with the exponential phase of cell growth (within the initial $24 \mathrm{~h}$ period), while solvent production commences after $24 \mathrm{~h}$.

During the fermentation with the PI side-stream, acetic acid with a maximum acid concentration equivalent to $3.94 \mathrm{~g} / \mathrm{L}$ was produced within the initial $24 \mathrm{~h}$ period and the concentration remained unchanged at the end of the fermentation process. Butyric acid was produced predominately after $48 \mathrm{~h}$, reaching a maximum acid concentration of $1.86 \mathrm{~g} / \mathrm{L}$ at $72 \mathrm{~h}$, while $5.1 \mathrm{~g} / \mathrm{L}$ of butanol produced at $24 \mathrm{~h}$ increased to a maximum yield $8.96 \mathrm{~g} / \mathrm{L}$ at $72 \mathrm{~h}$, thereby demonstrating the correlation between butyric acid and butanol production, as indicated in Fig. 4A. This finding agrees with previous studies, in which a high level of acetic acid production (5.9 g/L) did not significantly affect solventogenesis and butanol production (Qureshi et al. 2008). However, the initiation of solventogenesis correlates strongly with the concentration of undissociated butyric acid, at a minimum of $1.5 \mathrm{~g} / \mathrm{L}$ (Monot et al. 1984; Ibrahim et al. 2017).

Fermentation with low glucose consumption in both PII (6.7 g/L) and PIII (4.9 g/L) samples was immediate (at $0 \mathrm{~h}$ ) and butanol production was slowly increased to $4.38 \mathrm{~g} / \mathrm{L}$ and $4.91 \mathrm{~g} / \mathrm{L}$, respectively, by $72 \mathrm{~h}$. Low ABE fermentation rates in PII and PIII may have resulted from the fact that acids were produced more at the beginning of the process; a high butyric acid concentration $(2.55 \mathrm{~g} / \mathrm{L})$ was especially detected in PII during the initial $24 \mathrm{~h}$ fermentation period (shown at the left Fig. 4B). At the right Fig. 4B, an initial acidogenic phase between 0 and $24 \mathrm{~h}$ of fermentation was shown, during which glucose was consumed rapidly at the beginning of the first acidogenic phase, but the consumption rate of xylose was much slower. This finding was incompatible with the previous report of Pang et al. (2016), in which the glucose had suddenly increased after $24 \mathrm{~h}$ by adding a feeding fermentation medium. 
A

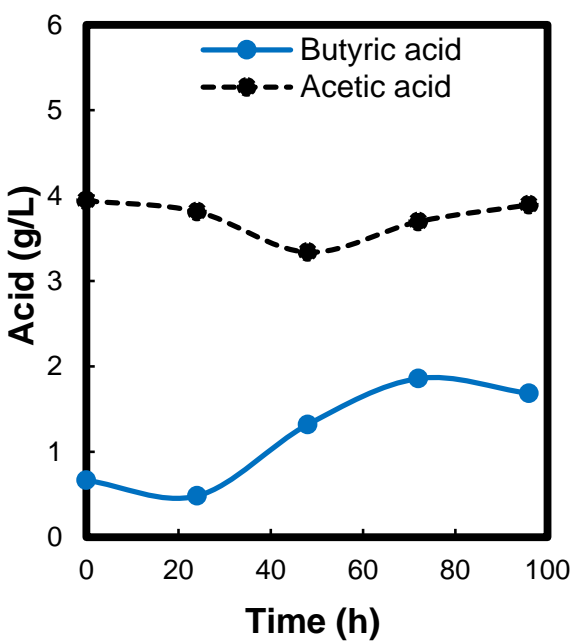

B

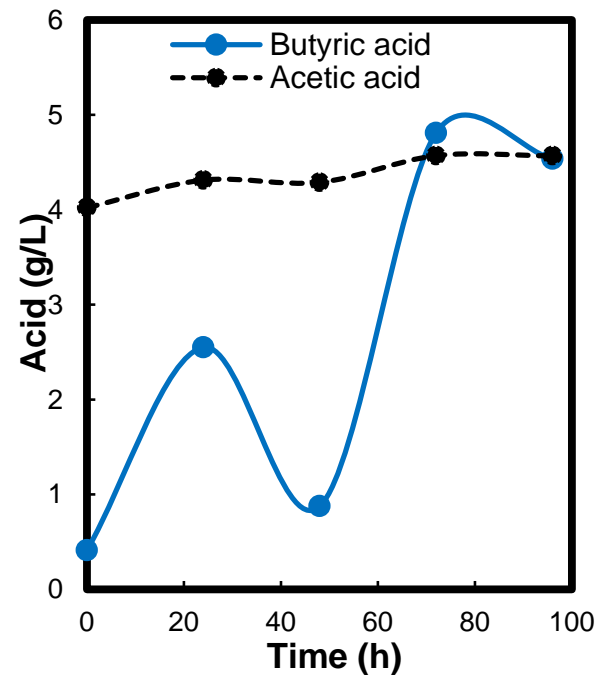

C

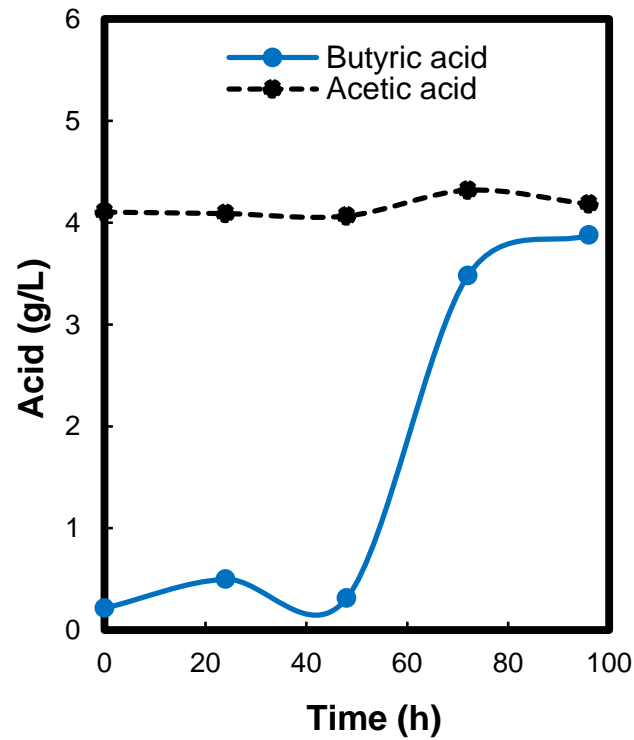

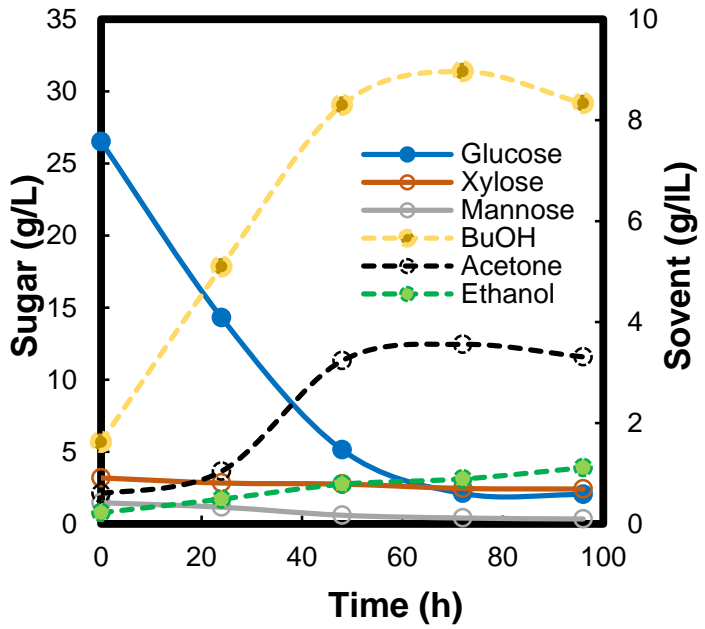
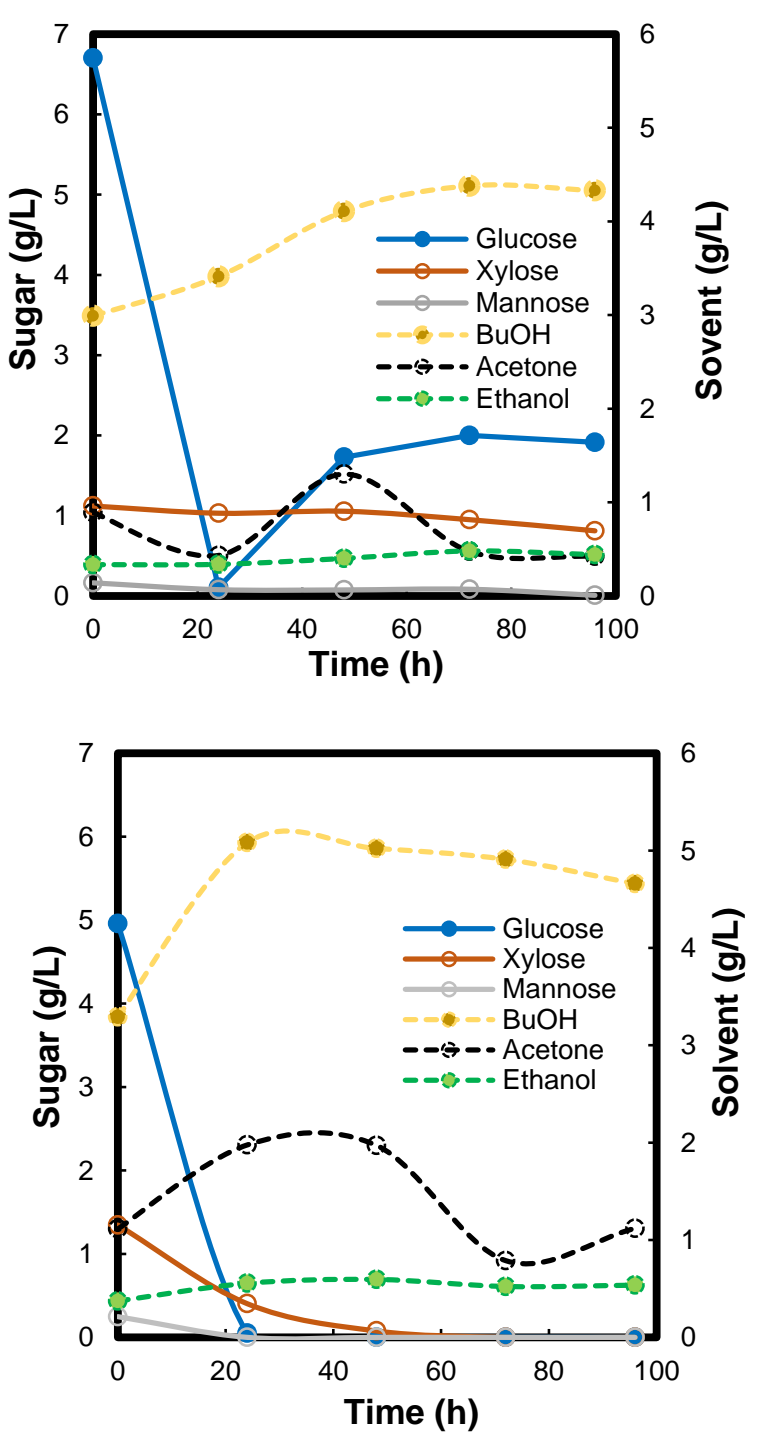

Fig. 4. ABE fermentation by $C$. acetobutylicum $D S M 1731$ using enzymatic hydrolysate of pulp and paper manufacturing process side-streams for 96 h: (A) PI, (B) PII, (C) PIII 
Therefore, the authors expressed it as an abnormal finding in typical research of ABE fermentation. Probably, PII experienced an "acid crash" or "acid flash" phenomena. An acid crash occurs under uncontrolled $\mathrm{pH}$ fermentation and results in the cessation of glucose uptake, acid, and butanol production. In contrast, an acid flash causes a weak fermentation in the solventogenic phase due to excessive acids or low $\mathrm{pH}$ (Maddox et al. 2000; Yang et al. 2013). Furthermore, all the sugars were not fully utilized in the PII sample, thereby indicating that the cells might have experienced an inhibitory effect during butanol production. A previous study reported that 7 and $10.5 \mathrm{~g} / \mathrm{L}$ of butanol were potent inhibitors of the growth of the organism and led to $50 \%$ inhibition of xylose and glucose incorporation into cell materials (Ounine et al. 1985).

At the $\log$ phase of cell growth, PI, PII, and PIII yielded $4.30 \mathrm{~g} / \mathrm{L}, 6.86 \mathrm{~g} / \mathrm{L}$, and $4.59 \mathrm{~g} / \mathrm{L}$ of total acids, respectively. The high concentration of acid production in all samples could have originated from the original side-streams. PII contained the greatest amount of total acids, and glucose uptake in PII ceased immediately after $24 \mathrm{~h}$. The sugar remained unconsumed $(1.91 \mathrm{~g} / \mathrm{L}$ remained after $96 \mathrm{~h})$, resulting in low solvent production $(5.2 \mathrm{~g} / \mathrm{L})$. This finding agrees with a previous report that a threshold amount of butyric acid initiates solvent production (Yang et al. 2013). However, an excess of acetic and butyric acid can be produced in the batch fermentation of $C$. acetobutylicum without $\mathrm{pH}$ control and subsequently causes a failure of transition from the acidogenic to the solventogenic phase, and the cessation of glucose utilization (Maddox et al. 2000). This finding also agrees with Ibrahim et al. (2015), who found that fermentation with an initial sugar concentration of $<40 \mathrm{~g} / \mathrm{L}$ yielded more acids than solvents during a $24 \mathrm{~h}$ fermentation period, and also inhibited cells after $48 \mathrm{~h}$ fermentation. Over $28 \%$ of the glucose in PII was not consumed due to the potential "acid flash" phenomenon rather than "acid crash", because total solvent production and the fermentation process were completed early in this experiment. During the initial $24 \mathrm{~h}$ fermentation period, glucose, xylose, and mannose were quickly consumed in the PIII sample; however, butyric acid production by $C$. acetobutylicum reached a plateau of $3.48 \mathrm{~g} / \mathrm{L}$ at $72 \mathrm{~h}$ (Fig. 4C).

The fermentation results show that acid and solvent can be produced at $0 \mathrm{~h}$ because cell growth can happen during inoculation, before the start of the $\mathrm{ABE}$ fermentation process. Theoretically, when the glucose concentration decreases, more acids are expected to re-assimilate for butanol production. Thus, acetic acid in the PIII sample remained unchanged throughout the fermentation process, while glucose was completely consumed, and acetone, butanol, and ethanol were produced. This finding explains why an acetic acid concentration of approximate $4 \mathrm{~g} / \mathrm{L}$ did not affect ABE fermentation. Although a linear correlation has been found between butanol and undissociated butyric acid concentrations (Monot et al. 1984; Hüsemann and Papoutsakis 1988), the presence of butyric acid in the medium after $48 \mathrm{~h}$ cannot enhance the production of butanol. This assumption is in agreement with a previous report, where butyric acid was required to start solventogenesis within $24 \mathrm{~h}$ and glucose utilization was stopped after $24 \mathrm{~h}$ without controlling $\mathrm{pH}$ (Yang et al. 2013). As a result, PIII produced 5.08 g/L butanol at $24 \mathrm{~h}$ and $4.91 \mathrm{~g} / \mathrm{L}$ at $72 \mathrm{~h}$, although its initial glucose yield was very low.

Table 5 documents results of several studies, showing that the ABE yields ( 0.22 to $0.38 \mathrm{~g} / \mathrm{g}$ sugars $)$ from the samples are comparable to other paper mill sludge values $(0.24$ to $0.29 \mathrm{~g} / \mathrm{g}$ sugars) and lignocellulosic biomass substrates, such as barley straw $(0.28 \mathrm{~g} / \mathrm{g}$ sugar) and sugarcane bagasse $(0.33 \mathrm{~g} / \mathrm{g}$ sugars $)$. A previous study reported that the final $\mathrm{ABE}$ solvent concentrations from paper sludge were 5 to $34 \%$ higher than that from dilute acid pretreated wheat straw (Guan et al. 2016). 
Table 5. Comparison of ABE Fermentation and Butanol Production from the Studied Pulp and Paper Side-streams and Other Biomass Sources

\begin{tabular}{|c|c|c|c|c|c|c|c|c|}
\hline Feedstock & $\begin{array}{l}\text { Pretreatment } \\
\text { Condition }\end{array}$ & $\begin{array}{c}\text { Enzymatic Hydrolysis } \\
\text { Condition }\end{array}$ & $\begin{array}{l}\text { Strain and } \\
\text { Fermentation } \\
\text { Method }\end{array}$ & $\begin{array}{l}\mathrm{BuOH} \\
(\mathrm{g} / \mathrm{L})\end{array}$ & $\begin{array}{c}\mathrm{BuOH} \\
\text { (g/g } \\
\text { Sugar) }\end{array}$ & $\begin{array}{l}\text { ABE } \\
(g / L)\end{array}$ & $\begin{array}{l}\mathrm{ABE} \\
\text { (g/g } \\
\text { Sugar) }\end{array}$ & References \\
\hline $\mathbf{P I}$ & \multirow{3}{*}{$\begin{array}{c}0.2 \% \mathrm{H}_{2} \mathrm{SO}_{4} \\
180{ }^{\circ} \mathrm{C}, 10 \mathrm{~min}\end{array}$} & \multirow{3}{*}{$\begin{array}{c}\text { cellulase } 10 \mathrm{FPU}, \\
\text { xylanase } 0.02 \%, 50^{\circ} \mathrm{C}, \\
48 \mathrm{~h}\end{array}$} & \multirow{3}{*}{$\begin{array}{l}\text { C. acetobutylicum } \\
\text { DSM 1731, BF }\end{array}$} & 8.33 & 0.25 & 12.76 & 0.38 & \multirow{3}{*}{ This study } \\
\hline PII & & & & 4.33 & 0.18 & 5.20 & 0.22 & \\
\hline PIII & & & & 4.66 & 0.19 & 6.32 & 0.26 & \\
\hline $\begin{array}{l}\text { Paper mill } \\
\text { sludge }\end{array}$ & $\begin{array}{c}15 \% \mathrm{NaOH} \\
140^{\circ} \mathrm{C}, 60 \mathrm{~min}\end{array}$ & nd & $\begin{array}{c}\text { C. sporogenes NCIM } \\
\text { 2337, BF }\end{array}$ & nd & nd & 0.559 & nd & $\begin{array}{l}\text { (Gogoi et al. } \\
\text { 2018) }\end{array}$ \\
\hline $\begin{array}{l}\text { Recycled } \\
\text { kraft paper } \\
\text { mill sludge }\end{array}$ & None & $10 \mathrm{FPU} / \mathrm{g}$-glucan & $\begin{array}{c}\text { C. acetobutylicum, } \\
\text { SSF }\end{array}$ & $6.8-9.7$ & nd & $10.6-17.1$ & $0.24-0.29$ & $\begin{array}{l}\text { (Guan et al. } \\
\text { 2016) }\end{array}$ \\
\hline $\begin{array}{l}\text { Sugarcane } \\
\text { bagasse }\end{array}$ & $\begin{array}{l}1 \% \mathrm{NaOH} \\
60^{\circ} \mathrm{C}, 72 \mathrm{~h}\end{array}$ & $\begin{array}{c}\text { cellulase } 10 \mathrm{FPU}, \beta- \\
\text { glucosidase } 160, \\
\text { CMCase } 90, \text { xylanase } \\
4600, \beta \text {-xylosidase } 18, \\
60^{\circ} \mathrm{C}, 64 \mathrm{~h}\end{array}$ & $\begin{array}{l}\text { C. acetobutylicum } \\
\text { GX01, FBF }\end{array}$ & 14.17 & 0.22 & 21.11 & 0.33 & $\begin{array}{l}\text { (Pang et al. } \\
\text { 2016) }\end{array}$ \\
\hline $\begin{array}{l}\text { Barley } \\
\text { straw }\end{array}$ & $\begin{array}{c}1.5 \% \mathrm{H}_{2} \mathrm{SO}_{4} \\
121^{\circ} \mathrm{C}, 60 \mathrm{~min}\end{array}$ & $\begin{array}{c}\text { cellulase } 10 \mathrm{FPU}, \\
\text { xylanase, surfactants } \\
(\mathrm{PEG} \text { and Tween }), 50^{\circ} \mathrm{C}, \\
48 \mathrm{~h}\end{array}$ & $\begin{array}{l}\text { C. acetobutylicum } \\
\text { DSM 1731, BF }\end{array}$ & 7.9 & 0.2 & 10.8 & 0.28 & $\begin{array}{l}\text { (Yang et al. } \\
\text { 2015) }\end{array}$ \\
\hline Rice straw & $\begin{array}{c}75 \% \text { ethanol, } \\
1 \% \mathrm{H}_{2} \mathrm{SO}_{4} \\
180^{\circ} \mathrm{C}, 30 \mathrm{~min}\end{array}$ & $\begin{array}{c}\text { cellulase } 25 \mathrm{FPU} \mathrm{\textrm {g } ^ { - 1 } , \beta -} \\
\text { glucosidase } 4 \mathrm{IU}^{-1}{ }^{-1} \\
45^{\circ} \mathrm{C}, 72 \mathrm{~h}\end{array}$ & $\begin{array}{l}\text { C. acetobutylicum } \\
\text { NRRL B-591, BF }\end{array}$ & 7.1 & nd & 10.5 & nd & $\begin{array}{l}\text { (Amiri et al. } \\
\text { 2014) }\end{array}$ \\
\hline $\begin{array}{l}\text { Switch } \\
\text { grass }\end{array}$ & $1 \% \mathrm{NaOH}$ & $\begin{array}{l}\text { Cellic CTec } 2 \text { cellulase } 15 \\
\text { FPU, } 50^{\circ} \mathrm{C}, 72 \mathrm{~h}\end{array}$ & $\begin{array}{c}\text { C. saccharobutylicum } \\
\text { DSM 13864, SHF }\end{array}$ & 13.0 & nd & 22.7 & 0.40 & $\begin{array}{c}\text { (Gao et al. } \\
\text { 2014) }\end{array}$ \\
\hline $\begin{array}{l}\text { Wheat } \\
\text { straw }\end{array}$ & $\begin{array}{c}1.6 \% \mathrm{NaOH} \\
2 \% \mathrm{H}_{2} \mathrm{O}_{2}, 35^{\circ} \mathrm{C}, \\
24 \mathrm{~h}\end{array}$ & $\begin{array}{c}\beta \text {-glucosidase } 60, \\
\text { CMCase } 119, \text { xylanase } \\
1554,45^{\circ} \mathrm{C}, 72 \mathrm{~h}\end{array}$ & $\begin{array}{l}\text { C. beijerinckii P260, } \\
\text { BF + Glc }\end{array}$ & 12.33 & 0.23 & 22.17 & 0.42 & $\begin{array}{c}\text { (Qureshi et al. } \\
\text { 2008) }\end{array}$ \\
\hline
\end{tabular}

BF: Batch fermentation; FBF: Fed-batch fermentation; SSF: Simutaneous saccharification fermentation; SHF: Separate hydrolysis and fermentation; Glc: glucose; nd: no data available 
In this study, PI yielded $12.76 \mathrm{~g} / \mathrm{L}$ of butanol, while PII and PIII yielded $5.20 \mathrm{~g} / \mathrm{L}$ and $6.32 \mathrm{~g} / \mathrm{L}$, respectively. (Table 5). The xylose utilization by C. acetobytylicum DSM 1731 was low in PI and PII, with $2.42 \mathrm{~g} / \mathrm{L}$ and $0.81 \mathrm{~g} / \mathrm{L}$ of xylose, respectively, remaining at the end of fermentation. This finding is consistent with Pang et al. (2016), who reported that $11 \mathrm{~g} / \mathrm{L}$ of xylose remained unconsumed (using C. acetobytylicum $\mathrm{GX01}$ ) after $72 \mathrm{~h}$ fermentation. In particular, the PI result is comparable to a previous study of recycled kraft paper mill sludge, in terms of solid loading (6.3 to 7.4\%), enzyme loading (10 FPU/gglucan), and ABE yield (10.6 to $17.1 \mathrm{~g} / \mathrm{L}$ ) (Guan et al. 2016).

The studied side-streams were from three different pulping processes, in which the quantity will diverge, affecting the feasibility of utilizing for butanol production. In general, a Finnish pulp (kraft) and linerboard mill generates about 4000 tonnes of primary sludge and 3000 tonnes of secondary sludge annually (Pöykiö et al. 2018). In the pulp and paper industry, kraft pulp mill is the primary candidate to be transformed into an integrated biorefining system. Recently, dissolving pulps have been produced by acid sulfite pulping or by pre-hydrolysis kraft pulping. The removal of hemicelluloses from wood and pulp is a recent technological advancement towards kraft-based dissolving pulp producing mills. The dissolving pulp process requires the production of high-purity cellulose (90 to $99 \%$ ) with low content of hemicellulose $(<4 \%)$ and traces of other components (Kumar and Christopher 2017). Therefore, the full utilization of different pulp side-streams requires either combination of feedstocks or adding new operations in the future, where an $\mathrm{ABE}$ plant would be installed next to the kraft pulp mill.

\section{CONCLUSIONS}

1. Based on the acetone-butanol-ethanol (ABE) fermentation yield results, the unwashed PI side-stream could be a potential feedstock for ABE fermentation, with an ABE yield of $0.38 \mathrm{~g} / \mathrm{g}$ sugar, in comparison to the unwashed PII and PIII side-streams, $0.22 \mathrm{~g} / \mathrm{g}$ and $0.26 \mathrm{~g} / \mathrm{g}$, respectively.

2. This study showed that washing did not influence sugar recovery in the PII and PIII prehydrolysate liquid samples. However, the prehydrolysate liquid of the washed PI sample contained sugars solubilized during the pretreatment when hemicellulosederived monomeric sugars were released into the liquid fraction (prehydrolysate).

3. The chemical compositions of the studied PI, PII, and PIII side-streams were similar, with the exception of PI, which contained the highest sugar content and the lowest lignin and ash contents. Therefore, the enzymatic hydrolysate of the unwashed PI sidestream resulted in the highest sugar concentration $(0.68 \mathrm{~g} / \mathrm{g})$. Moreover, the unwashed PI side-stream was found to be the best choice among the studied samples for bio-based butanol production, with a butanol yield of $0.25 \mathrm{~g} / \mathrm{g}$ sugar.

\section{ACKNOWLEDGMENTS}

The authors gratefully acknowledge the financial support from the projects "Sustainable production concepts on integrated biorefining systems (SusBioRef)" funded by the Academy of Finland and "Reaching congenial region through the valorization of municipal and industrial wastewaters and sludge" funded by the Karelia Cross-border cooperation 
program (project number KA4020).

\section{REFERENCES CITED}

Abdullah, R., Ishak, C., Kadir, W., and Bakar, R. (2015). "Characterization and feasibility assessment of recycled paper mill sludges for land application in relation to the environment," International Journal of Environmental Research and Public Health 12(8), 9314-9329. DOI: 10.3390/ijerph120809314

Amidon, T. E., Wood, C. D., Shupe, A. M., Wang, Y., Graves, M., and Liu, S. (2008). "Biorefinery: Conversion of Woody Biomass to Chemicals, Energy and Materials," Journal of Biobased Materials and Bioenergy 2(2), 100-120. DOI: 10.1166/jbmb.2008.302

Amiri, H., Karimi, K., and Zilouei, H. (2014). "Organosolv pretreatment of rice straw for efficient acetone, butanol, and ethanol production," Bioresource Technology 152, 450-456. DOI: 10.1016/j.biortech.2013.11.038

Ashrafi, O., Yerushalmi, L., and Haghighat, F. (2015). "Wastewater treatment in the pulp-and-paper industry: A review of treatment processes and the associated greenhouse gas emission," Journal of Environmental Management 158, 146-157. DOI: 10.1016/j.jenvman.2015.05.010

Bajpai, P. (2015). "Generation of waste in pulp and paper mills," in: Management of Pulp and Paper Mill Waste, P. Bajpai (ed.), Springer International Publishing, Amsterdam, pp. 9-17. DOI: 10.1007/978-3-319-11788-1_2

Boshoff, S., Gottumukkala, L. D., van Rensburg, E., and Görgens, J. (2016). "Paper sludge (PS) to bioethanol: Evaluation of virgin and recycle mill sludge for low enzyme, high-solids fermentation," Bioresource Technology 203, 103-111. DOI: 10.1016/j.biortech.2015.12.028

Dürre, P. (2008). "Fermentative butanol production: Bulk chemical and biofuel," Annals of the New York Academy of Sciences 1125, 353-362. DOI: 10.1196/annals.1419.009

FFI. (2018). "Finnish Forest Industries," Finnish Forest Industries, <https://www.forestindustries.fi/statistics/environment/> (Nov. 3, 2019).

Galbe, M., and Zacchi, G. (2007). "Pretreatment of lignocellulosic materials for efficient bioethanol production," Advances in Biochemical Engineering/Biotechnology 108, 41-65. DOI: 10.1007/10_2007_070

Gao, K., Boiano, S., Marzocchella, A., and Rehmann, L. (2014). "Cellulosic butanol production from alkali-pretreated switchgrass (Panicum virgatum) and phragmites (Phragmites australis)," Bioresource Technology 174, 176-181. DOI: 10.1016/j.biortech.2014.09.152

Gavrilescu, D. (2008). "Energy from biomass in pulp and paper mills," Environmental Engineering and Management Journal 7(5), 537-546. DOI: 10.30638/eemj.2008.077

Gogoi, H., Nirosha, V., Jayakumar, A., Prabhu, K., Maitra, M., and Panjanathan, R. (2018). "Paper mill sludge as a renewable substrate for the production of acetonebutanol-ethanol using Clostridium sporogenes NCIM 2337," Energy Sources Part Arecovery Utilization and Environmental Effects 40(1), 39-44. DOI: 10.1080/15567036.2017.1405107

Gottumukkala, L. D., Haigh, K., Collard, F.-X., van Rensburg, E., and Görgens, J. (2016). "Opportunities and prospects of biorefinery-based valorisation of pulp and paper sludge," Bioresource Technology 215, 37-49. DOI: 
10.1016/j.biortech.2016.04.015

Guan, W., Shi, S., Tu, M., and Lee, Y. Y. (2016). "Acetone-butanol-ethanol production from Kraft paper mill sludge by simultaneous saccharification and fermentation," Bioresource Technology 200, 713-721. DOI: 10.1016/j.biortech.2015.10.102

Hassan, Md. K., Villa, A., Kuittinen, S., Jänis, J., and Pappinen, A. (2019). “An assessment of side-stream generation from Finnish forest industry," Journal of Material Cycles and Waste Management 21(2), 265-280. DOI: 10.1007/s10163-0180787-5

Hayes, D. J. M. (2012). “Development of near infrared spectroscopy models for the quantitative prediction of the lignocellulosic components of wet Miscanthus samples," Bioresource Technology 119, 393-405. DOI: 10.1016/j.biortech.2012.05.137

He, Y., Fang, Z., Zhang, J., Li, X., and Bao, J. (2014). “De-ashing treatment of corn stover improves the efficiencies of enzymatic hydrolysis and consequent ethanol fermentation," Bioresource Technology 169, 552-558. DOI: 10.1016/j.biortech.2014.06.088

Hirsch, A., and Grinsted, E. (1954). "Methods for the growth and enumeration of anaerobic spore-formers from cheese, with observations on the effect of nisin," Journal of Dairy Research 21(1), 101-110. DOI: 10.1017/S0022029900007196

Huang, C., Wu, X., Huang, Y., Lai, C., Li, X., and Yong, Q. (2016). "Prewashing enhances the liquid hot water pretreatment efficiency of waste wheat straw with high free ash content," Bioresource Technology 219, 583-588. DOI: 10.1016/j.biortech.2016.08.018

Hüsemann, M. H. W., and Papoutsakis, E. T. (1988). "Solventogenesis in Clostridium acetobutylicum fermentations related to carboxylic acid and proton concentrations," Biotechnology and Bioengineering 32(7), 843-852. DOI: 10.1002/bit.260320702

Ibrahim, M. F., Linggang, S., Jenol, M. A., Yee, P. L., and Abd-Aziz, S. (2015). "Effect of buffering system on acetone-butanol-ethanol fermentation by Clostridium acetobutylicum ATCC 824 using pretreated oil palm empty fruit bunch," BioResources 10(3), 3890-3907. DOI: 10.15376/biores.10.3.3890-3907

Ibrahim, M. F., Ramli, N., Kamal Bahrin, E., and Abd-Aziz, S. (2017). "Cellulosic biobutanol by Clostridia: Challenges and improvements," Renewable and Sustainable Energy Reviews 79, 1241-1254. DOI: 10.1016/j.rser.2017.05.184

Jiang, W., Wen, Z., Wu, M., Li, H., Yang, J., Lin, J., Lin, Y., Yang, L., and Cen, P. (2014). "The effect of $\mathrm{pH}$ control on acetone-butanol-ethanol fermentation by Clostridium acetobutylicum ATCC 824 with xylose and d-glucose and d-xylose mixture," Chinese Journal of Chemical Engineering 22(8), 937-942. DOI: 10.1016/j.cjche.2014.06.003

Kang, L., Lee, Y., Yoon, S.-H., Smith, A., and Krishnagopalan, G. (2012). "Ethanol production from the mixture of hemicellulose prehydrolysate and paper sludge," Bioresources 7(3), 3607-3626. DOI: 10.15376/biores.7.3.3607-3626

Kang, L., Wang, W., and Lee, Y. Y. (2010). "Bioconversion of kraft paper mill sludges to ethanol by SSF and SSCF," Applied Biochemistry and Biotechnology 161(1-8), 53-66. DOI: 10.1007/s12010-009-8893-4

Karimi, K., Tabatabaei, M., Sárvári Horváth, I., and Kumar, R. (2015). "Recent trends in acetone, butanol, and ethanol (ABE) production," Biofuel Research Journal 2(4), 301-308. DOI: 10.18331/BRJ2015.2.4.4

Kjeldahl, J. (1883). "Neue Methode zur Bestimmung des Stickstoffs in organischen 
Körpern," Zeitschrift für analytische Chemie 22(1), 366-382. DOI:

10.1007/BF01338151

Kostamo, A., Holmbom, B., and Kukkonen, J. V. K. (2004). "Fate of wood extractives in wastewater treatment plants at kraft pulp mills and mechanical pulp mills," Water Research 38(4), 972-982. DOI: 10.1016/j.watres.2003.10.051

Kumar, H., and Christopher, L. P. (2017). "Recent trends and developments in dissolving pulp production and application," Cellulose, 24(6), 2347-2365. DOI: 10.1007/s10570-017-1285-y

Kumar, P., Barrett, D. M., Delwiche, M. J., and Stroeve, P. (2009). "Methods for pretreatment of lignocellulosic biomass for efficient hydrolysis and biofuel production," Industrial \& Engineering Chemistry Research 48(8), 3713-3729. DOI: 10.1021/ie801542g

Kuokkanen, T., Nurmesniemi, H., Pöykiö, R., Kujala, K., Kaakinen, J., and Kuokkanen, M. (2008). "Chemical and leaching properties of paper mill sludge," Chemical Speciation \& Bioavailability 20(2), 111-122. DOI: 10.3184/095422908X324480

Maddox, I. S., Steiner, E., Hirsch, S., Wessner, S., Gutierrez, N. A., Gapes, J. R., and Schuster, K. C. (2000). "The cause of 'acid-crash' and 'acidogenic fermentations' during the batch acetone-butanol-ethanol (ABE-) fermentation process," Journal of Molecular Microbiology and Biotechnology 2(1), 95-100.

Marques, S., Santos, J. A. L., Gírio, F. M., and Roseiro, J. C. (2008). "Lactic acid production from recycled paper sludge by simultaneous saccharification and fermentation," Biochemical Engineering Journal 41(3), 210-216. DOI: 10.1016/j.bej.2008.04.018

Mendes, C. V. T., Rocha, J. M. S., and Carvalho, M. G. V. S. (2014). "Valorization of residual streams from pulp and paper mills: Pretreatment and bioconversion of primary sludge to bioethanol," Industrial \& Engineering Chemistry Research 53(50), 19398-19404. DOI: 10.1021/ie503021y

Méndez, A., Fidalgo, J. M., Guerrero, F., and Gascó, G. (2009). "Characterization and pyrolysis behaviour of different paper mill waste materials," Journal of Analytical and Applied Pyrolysis 86(1), 66-73. DOI: 10.1016/j.jaap.2009.04.004

Miller, G. L. (1959). "Use of dinitrosalicylic acid reagent for determination of reducing sugar," Analytical Chemistry 31(3), 426-428. DOI: 10.1021/ac60147a030

MMM (24/2011). (2013). "Fertiliser products - Maa- ja metsätalousministeriö," Decree of the Ministry of Agriculture and Forestry on Fertiliser Products, $<$ https://mmm.fi/en/animals-and-plants/fertiliser-products> (Jan. 13, 2020).

Monot, F., Engasser, J.-M., and Petitdemange, H. (1984). "Influence of pH and undissociated butyric acid on the production of acetone and butanol in batch cultures of Clostridium acetobutylicum," Applied Microbiology and Biotechnology 19(6), 422426. DOI: 10.1007/BF00454381

Ounine, K., Petitdemange, H., Raval, G., and Gay, R. (1985). "Regulation and butanol inhibition of D-xylose and D-glucose uptake in Clostridium acetobutylicum," Applied and Environmental Microbiology 49(4), 874-878.

Pang, Z.-W., Lu, W., Zhang, H., Liang, Z.-W., Liang, J.-J., Du, L.-W., Duan, C.-J., and Feng, J.-X. (2016). "Butanol production employing fed-batch fermentation by Clostridium acetobutylicum GX01 using alkali-pretreated sugarcane bagasse hydrolysed by enzymes from Thermoascus aurantiacus QS 7-2-4," Bioresource Technology 212, 82-91. DOI: 10.1016/j.biortech.2016.04.013

Pätäri, S., Kyläheiko, K., and Sandström, J. (2011). "Opening up new strategic options in 
the pulp and paper industry: Case biorefineries," Forest Policy and Economics 13(6), 456-464. DOI: 10.1016/j.forpol.2011.06.003

Phillips, R. B., Jameel, H., and Chang, H. M. (2013). "Integration of pulp and paper technology with bioethanol production," Biotechnology for Biofuels 6(1), 13. DOI: 10.1186/1754-6834-6-13

Pöykiö, R., Watkins, G., and Dahl, O. (2018). "Characterization of primary and secondary wastewater treatment sludge from a pulp and board mill complex to evaluate the feasibility of utilization as a soil amendment agent and a fertilizer product," Journal of Bioresources and Bioproducts 3(3), 88-95. DOI:

10.21967/JBB.V3I3.174

Qureshi, N., Saha, B. C., Hector, R. E., and Cotta, M. A. (2008). "Removal of fermentation inhibitors from alkaline peroxide pretreated and enzymatically hydrolyzed wheat straw: Production of butanol from hydrolysate using Clostridium beijerinckii in batch reactors," Biomass and Bioenergy 32(12), 1353-1358. DOI: 10.1016/j.biombioe.2008.04.009

Rahman, H., Lindström, M. E., Sandström, P., Salmén, L., and Engstrand, P. (2017). "The effect of increased pulp yield using additives in the softwood kraft cook on the physical properties of lowgrammage handsheets," Nordic Pulp \& Paper Research Journal 32(3), 317-323. DOI: 10.3183/npprj-2017-32-03-p317-323

Rozich, A. F., and Gaudy, A. F. (1992). Design and Operation of Activated Sludge Processes Using Respirometry, Lewis Publishers, Boca Raton.

Rydholm, S. A. (1965). "Chemical pulping," in: Pulping Processes, Interscience Publishers, New York, NY, pp. 439-575.

Saville, A. B. (2011). "Pretreatment options," in: Plant Biomass Conversion, E. Hood, P. Nelson, R. Powell (eds.), John Wiley \& Sons, Ames, Iowa, pp.199-224.

Shi, S., Kang, L., and Lee, Y. Y. (2015). "Production of lactic acid from the mixture of softwood pre-hydrolysate and paper mill sludge by simultaneous saccharification and fermentation," Applied Biochemistry and Biotechnology 175(5), 2741-2754. DOI: 10.1007/s12010-014-1451-8

Simão, L., Hotza, D., Raupp-Pereira, F., Labrincha, J. A., Montedo, O. R. K., Simão, L., Hotza, D., Raupp-Pereira, F., Labrincha, J. A., and Montedo, O. R. K. (2018). "Wastes from pulp and paper mills - A review of generation and recycling alternatives," Cerâmica 64(371), 443-453. DOI: 10.1590/0366-69132018643712414

Sluiter, A., Hames, B., Ruiz, R., Scarlata, C., Sluiter, J., and Templeton, D. (2008a). Determination of Ash in Biomass (NREL/TP-510-42622), National Renewable Energy Laboratory, Golden, CO, USA.

Sluiter, A., Hames, B., Hyman, D., Payne, C., Ruiz, R., Scarlata, C., Sluiter, J., Templeton, D., and Wolfe, J. (2008b). Determination of Total Solids in Biomass and Total Dissolved Solids in Liquid Process Samples (NREL/TP-510-42621), National Renewable Energy Laboratory, Golden, CO, USA.

Talebnia, F., Karakashev, D., and Angelidaki, I. (2010). "Production of bioethanol from wheat straw: An overview on pretreatment, hydrolysis and fermentation," Bioresource Technology 101(13), 4744-4753. DOI: 10.1016/j.biortech.2009.11.080

Tang, W., Wu, X., Huang, C., Huang, C., Lai, C., and Yong, Q. (2019). "Enhancing enzymatic digestibility of waste wheat straw by presoaking to reduce the ashinfluencing effect on autohydrolysis," Biotechnology for Biofuels 12, 222. DOI: 10.1186/s13068-019-1568-7

Tashiro, Y., Yoshida, T., Noguchi, T., and Sonomoto, K. (2013). "Recent advances and 
future prospects for increased butanol production by acetone-butanol-ethanol fermentation," Engineering in Life Sciences 13(5), 432-445. DOI:

10.1002/elsc. 201200128

Wegner, T. H., Houtman, C. J., Rudie, A. W., Illman, B. L., Ince, P. J., Bilek, E. M., and Jeffries, T. W. (2012). "Prehydrolysis pulping with fermentation coproducts," in: Green Chemistry Series, L. Christopher (ed.), Royal Society of Chemistry, Cambridge, Ch. 6, pp. 134-150. DOI: 10.1039/9781849735063-00134

Yang, M., Kuittinen, S., Zhang, J., Vepsäläinen, J., Keinänen, M., and Pappinen, A. (2015). "Co-fermentation of hemicellulose and starch from barley straw and grain for efficient pentoses utilization in acetone-butanol-ethanol production," Bioresource Technology 179, 128-135. DOI: 10.1016/j.biortech.2014.12.005

Yang, X., Tu, M., Xie, R., Adhikari, S., and Tong, Z. (2013). “A comparison of three pH control methods for revealing effects of undissociated butyric acid on specific butanol production rate in batch fermentation of Clostridium acetobutylicum," AMB Express 3(1), 3. DOI: 10.1186/2191-0855-3-3

Article submitted: April 13, 2020; Peer review completed: June 28, 2020; Revised version received and accepted: August 9, 2020; Published: October 22, 2020.

DOI: 10.15376/biores.15.4.9265-9290 


\section{SUPPLEMENTARY MATERIAL}

Following an assessment of suitable pretreatment conditions for the studied sidestreams, PI was selected for further testing because of its potential chemical composition and high total sugar content. It was pretreated under a range of conditions with water: $0.1 \%$ and $0.2 \% \mathrm{H}_{2} \mathrm{SO}_{4}$ at $180{ }^{\circ} \mathrm{C}$ and $200{ }^{\circ} \mathrm{C}$ for $10,20,30,45$, and $60 \mathrm{~min}$ (Fig. S1). The applied pretreatment was not excessively strong because it would lead to sugar loss through the degradation of hemicellulosic and cellulosic sugars to furans, such as furfural, HMF (5 hydroxymethylfurfural), and to organic acids, such as formic acid and levulinic acid (Karimi et al. 2015). In this study, undesired inhibitory compounds, such as furfural, HMF, acetic acid, and formic acid, were released during the water and dilute acid pretreatment. These sugar degradation products, present in the pretreated hydrolysate liquid fraction, were formed at high temperatures $\left(200{ }^{\circ} \mathrm{C}\right)$ or during an extended pretreatment time (30, 45, and $60 \mathrm{~min}$ ) (Fig. S1). The main interest here was to produce butanol from the cellulosic sugars of the pretreated pulp and paper manufacturing side-streams, and therefore pretreatment with $0.2 \% \mathrm{H}_{2} \mathrm{SO}_{4}$ at $180{ }^{\circ} \mathrm{C}$ for 10 min was selected for all studied samples (i.e., PI, PII, and PIII).

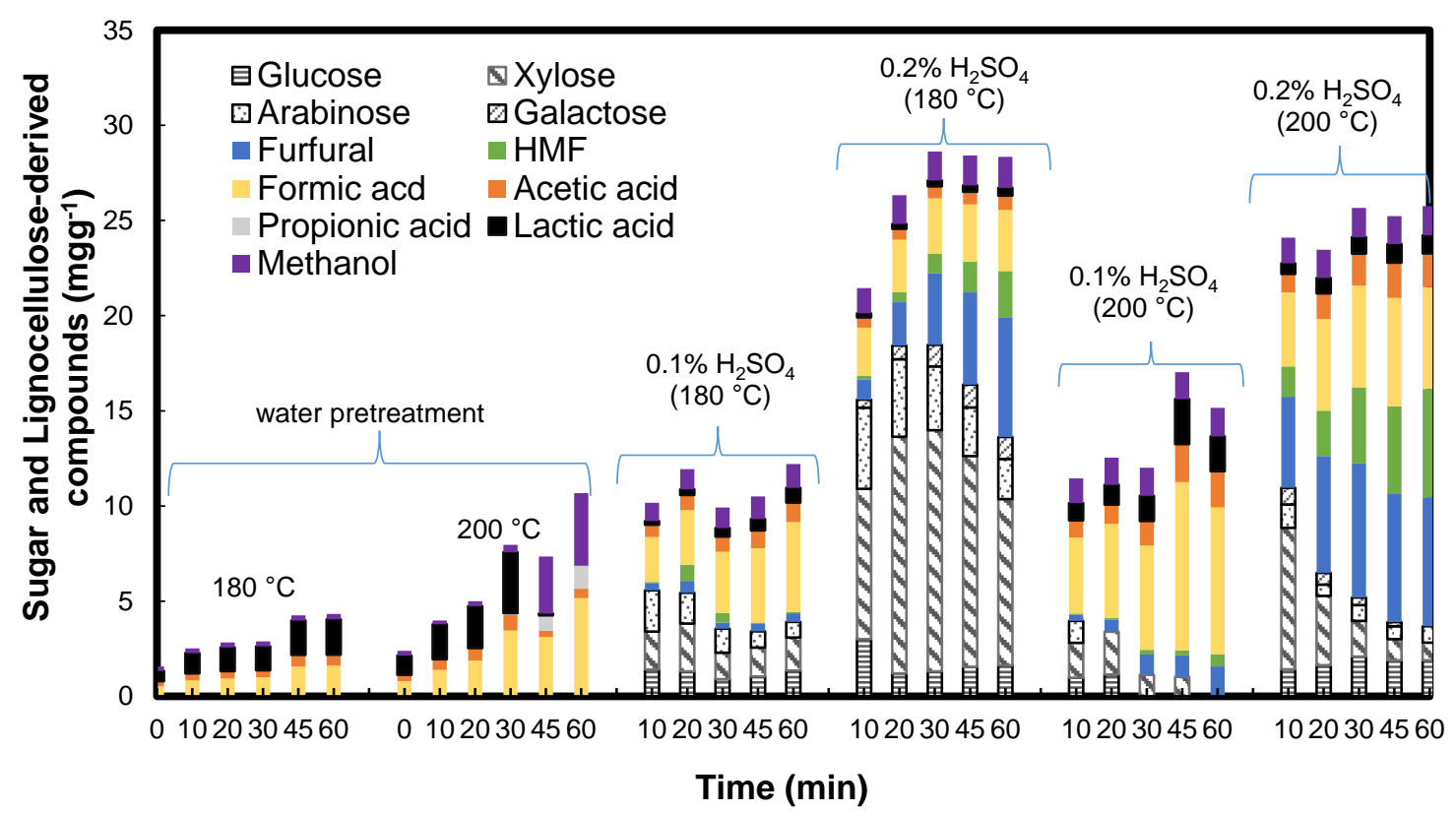

Fig. S1. Sugar and inhibitor contents in the prehydrolysate liquid fraction of the PI side-stream under different pretreatment conditions: water, $0.1 \%$ and $0.2 \% \mathrm{H}_{2} \mathrm{SO}_{4}$ at $180{ }^{\circ} \mathrm{C}$ and $200{ }^{\circ} \mathrm{C}$

To determine a suitable DM loading for subsequent enzymatic hydrolysis and fermentation, PI was hydrolyzed (with a range of DM loadings: $2 \%, 5 \%, 7 \%$, and 10\%) for $48 \mathrm{~h}$ under two variable conditions: untreated and washed prior to $0.2 \%$ sulfuric acid at 180 ${ }^{\circ} \mathrm{C}$. When the DM loading reached $7 \%$, the sugar concentration in the PI washed sample pretreated with $0.2 \% \mathrm{H}_{2} \mathrm{SO}_{4}$ at $180{ }^{\circ} \mathrm{C}$ rose from $22.3 \mathrm{~g} / \mathrm{L}$ to $34.7 \mathrm{~g} / \mathrm{L}$ (Fig. S2A). From an economic point of view, $7 \%$ DM loading for fermentation is favorable, as an almost similar sugar concentration is produced at $7 \%(34.7 \mathrm{~g} / \mathrm{L})$ and $10 \%(35.5 \mathrm{~g} / \mathrm{L})$ in the washed sample at $180{ }^{\circ} \mathrm{C}$. Therefore, $7 \% \mathrm{DM}$ loading was chosen for enzymatic hydrolysis of all the tested samples (i.e., PI, PII, and PIII).

Enzymatic digestion of lignocellulosic materials requires synergistic interaction of 
a group of different enzymes: cellulase, endoglucanases, and cellobiohydrolases, as well as a variety of hemicellulases, such as xylanases and mannanases. Total reducing sugars following hydrolysis with cellulase (CEL) were $5.15 \mathrm{~g} / \mathrm{L}$ and $3.6 \mathrm{~g} / \mathrm{L}$ for the PI unwashed and the washed control, respectively, and were $5.24 \mathrm{~g} / \mathrm{L}$ and $5.32 \mathrm{~g} / \mathrm{L}$, respectively, for the $0.2 \% \mathrm{H}_{2} \mathrm{SO}_{4}$ pretreatment (Fig. S2B). By adding $2 \mathrm{~g} / 100 \mathrm{~g} \mathrm{DM}$ xylanase (CEL+XYL), the glucose concentrations in the unwashed and the washed control PI samples increased to $6.2 \mathrm{~g} / \mathrm{L}$ and $3.7 \mathrm{~g} / \mathrm{L}$, respectively, whereas the samples with $0.2 \% \mathrm{H}_{2} \mathrm{SO}_{4}$ pretreatment were $5.47 \mathrm{~g} / \mathrm{L}$ and $5.68 \mathrm{~g} / \mathrm{L}$, respectively (Fig. S2B). The results showed that the synergistic interaction of xylanase and cellulase enzymes improved the hydrolysis of cellulose accessibility by removing the hemicellulose shields that cover the cellulose.

In this study, the raw pulp and paper manufacturing process side-streams were subjected to a washing process before dilute acid pretreatment and enzymatic hydrolysis. However, the enzymatic hydrolysate of the PI unwashed sample with $0.2 \% \mathrm{H}_{2} \mathrm{SO}_{4}$ pretreatment exhibited the highest glucose concentration $(6.94 \mathrm{~g} / \mathrm{L})$ at $48 \mathrm{~h}$ (Fig. S2C).

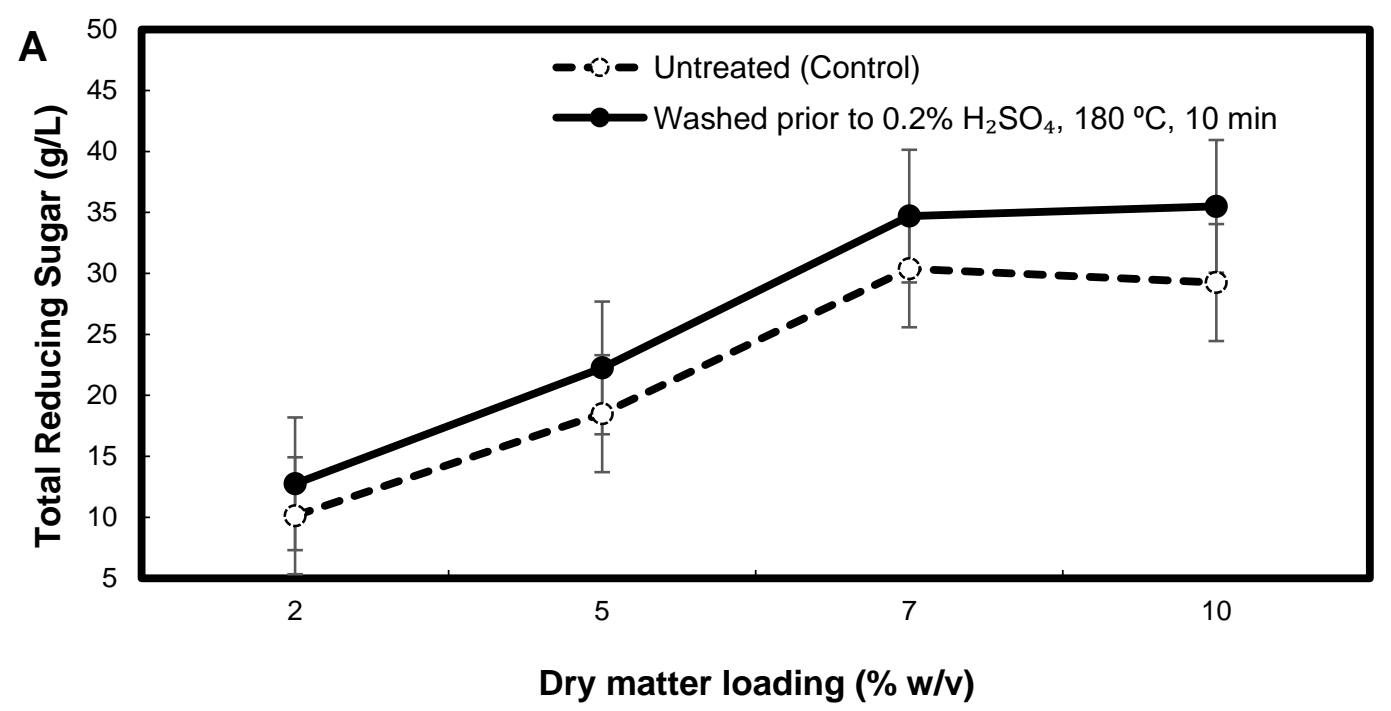




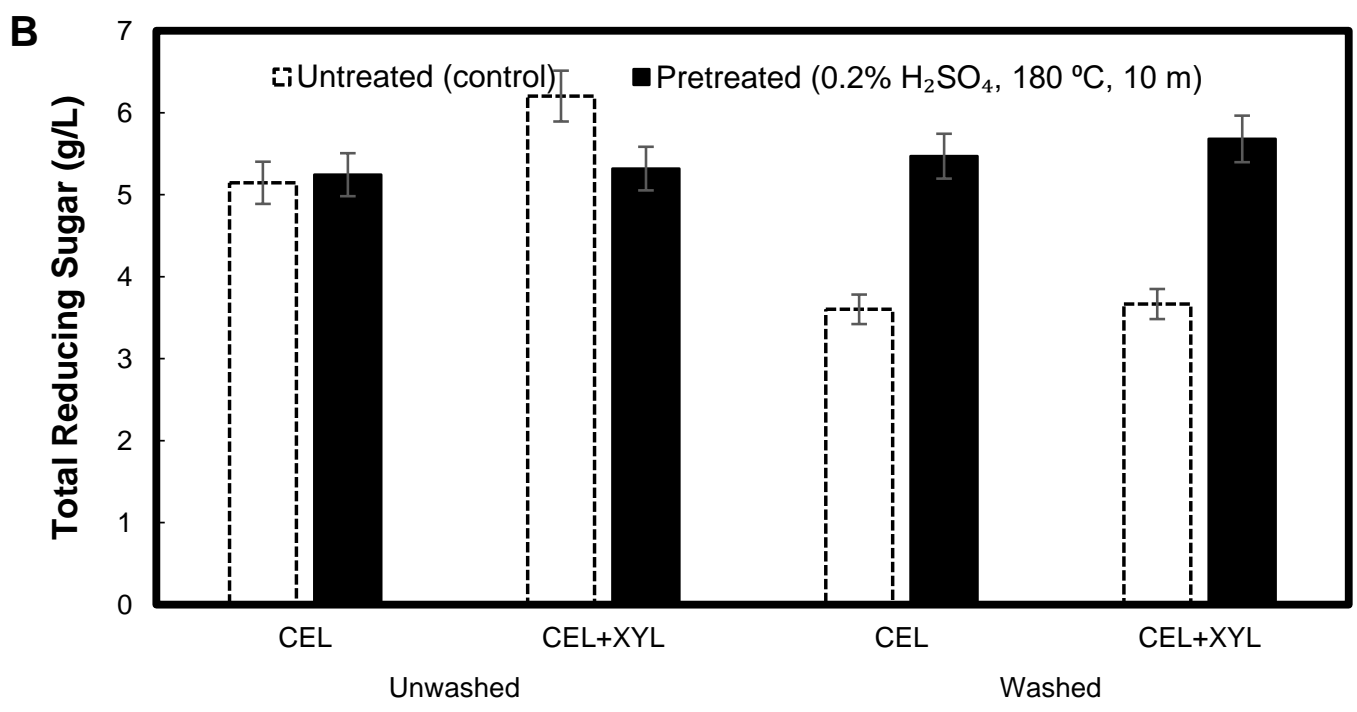

Enzyme system

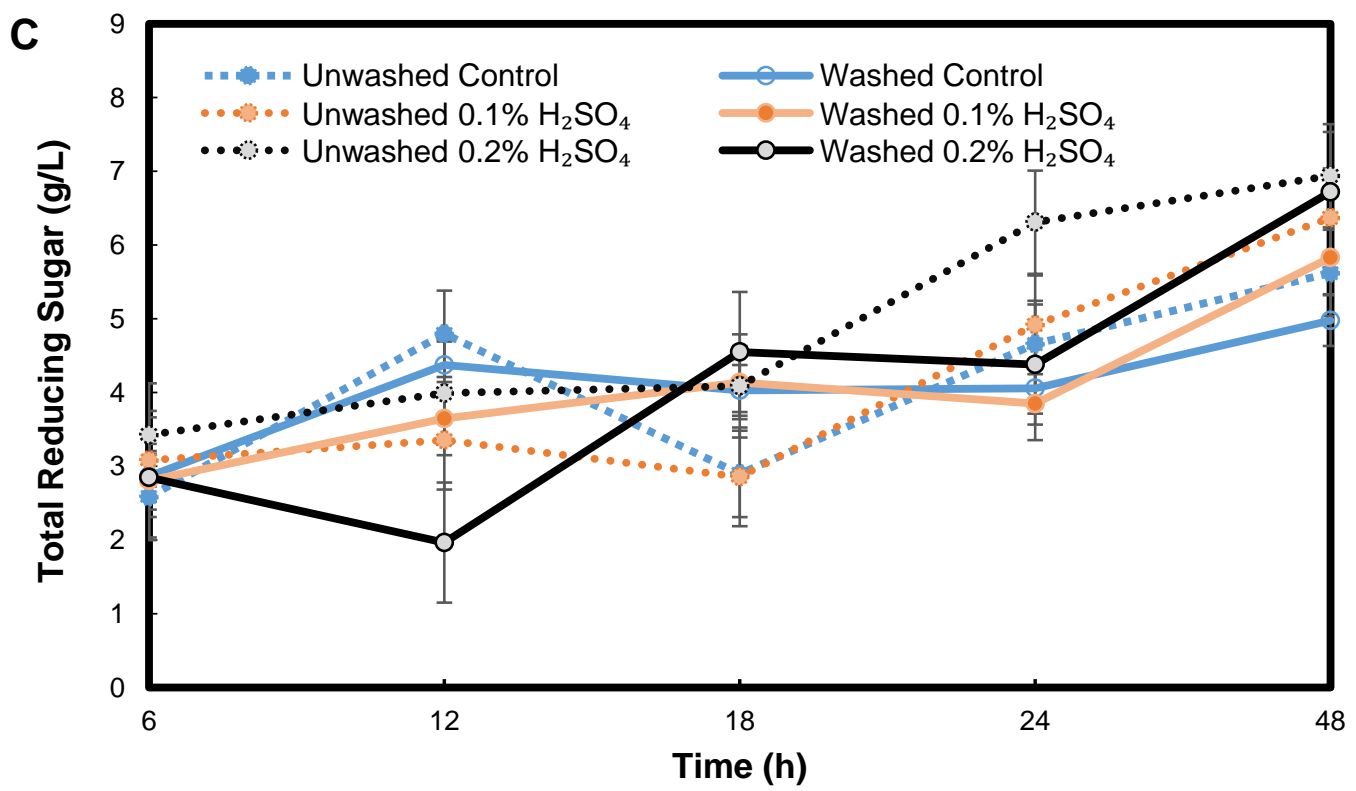

Fig. S2. Enzymatic hydrolysis of PI side-stream after $48 \mathrm{~h}(\mathrm{~A})$ Sugars recovery in different dry matter loading; (B) Comparison of sugar concentration between CEL (Celluclast $1.5 \mathrm{~L}$ and Novozyme 188) and CEL+XYL (Xylanase); (C) Kinetic reducing sugar production under three different conditions: Control (untreated), unwashed and washed prior to pretreatment $0.1 \%$ and $0.2 \% \mathrm{H}_{2} \mathrm{SO}_{4}, 180{ }^{\circ} \mathrm{C}$ for $10 \mathrm{~min}$. (Error bars represent one standard deviation.) 